\title{
Review \\ Chimeric Antigen Receptor Design and Efficacy in Ovarian Cancer Treatment
}

\author{
Katarzyna M. Terlikowska ${ }^{1}$ (D), Bożena Dobrzycka ${ }^{2}$ and Sławomir J. Terlikowski ${ }^{3, *}$ \\ 1 Department of Food Biotechnology, Medical University of Bialystok, Szpitalna 37 Street, \\ 15-295 Bialystok, Poland; kterlikowska@gmail.com \\ 2 Department of Gynaecology and Obstetrics, Medical University of Bialystok, M. Sklodowskiej-Curie 24A \\ Street, 15-089 Bialystok, Poland; bdobrzycka@gmail.com \\ 3 Department of Obstetrics, Gynaecology and Maternity Care, Medical University of Bialystok, \\ Szpitalna 37 Street, 15-295 Bialystok, Poland \\ * Correspondence: sterlikowski@gmail.com; Tel.: +48-(85)-686-50-36; Fax: +48-(85)-686-50-37
}

Citation: Terlikowska, K.M.; Dobrzycka, B.; Terlikowski, S.J. Chimeric Antigen Receptor Design and Efficacy in Ovarian Cancer Treatment. Int. J. Mol. Sci. 2021, 22, 3495. https://doi.org/10.3390/ ijms22073495

Academic Editor: Matthias Nees

Received: 11 February 2021

Accepted: 24 March 2021

Published: 28 March 2021

Publisher's Note: MDPI stays neutral with regard to jurisdictional claims in published maps and institutional affiliations.

Copyright: (c) 2021 by the authors. Licensee MDPI, Basel, Switzerland. This article is an open access article distributed under the terms and conditions of the Creative Commons Attribution (CC BY) license (https:// creativecommons.org/licenses/by/ $4.0 /)$.

\begin{abstract}
Our increased understanding of tumour biology gained over the last few years has led to the development of targeted molecular therapies, e.g., vascular endothelial growth factor A (VEGF-A) antagonists, poly[ADP-ribose] polymerase 1 (PARP1) inhibitors in hereditary breast and ovarian cancer syndrome (BRCA1 and BRCA2 mutants), increasing survival and improving the quality of life. However, the majority of ovarian cancer (OC) patients still do not have access to targeted molecular therapies that would be capable of controlling their disease, especially resistant or relapsed. Chimeric antigen receptors (CARs) are recombinant receptor constructs located on $\mathrm{T}$ lymphocytes or other immune cells that change its specificity and functions. Therefore, in a search for a successful solid tumour therapy using CARs the specific cell surface antigens identification is crucial. Numerous in vitro and in vivo studies, as well as studies on humans, prove that targeting overexpressed molecules, such as mucin 16 (MUC16), annexin 2 (ANXA2), receptor tyrosine-protein kinase erbB-2 (HER2/neu) causes high tumour cells toxicity and decreased tumour burden. CARs are well tolerated, side effects are minimal and they inhibit disease progression. However, as OC is heterogenic in its nature with high mutation diversity and overexpression of different receptors, there is a need to consider an individual approach to treat this type of cancer. In this publication, we would like to present the history and status of therapies involving the CAR T cells in treatment of OC tumours, suggest potential $\mathrm{T}$ cell-intrinsic determinants of response and resistance as well as present extrinsic factors impacting the success of this approach.
\end{abstract}

Keywords: chimeric antigen receptors; ovarian cancer; relapse; chemoresistance

\section{Introduction}

Ovarian cancer (OC) is the 8th most common form of cancer in women worldwide with an estimated 295,414 new cases and 184,799 deaths annually. It has the worst prognosis and the highest mortality rate among gynaecological cancers [1]. Moreover, it is predicted that by the year 2040 the mortality rate of this specific type of cancer will rise significantly $[2,3]$. OC develops asymptomatic, and there is no proper screening program that would facilitate early-stage diagnosis [4,5]. OC metastasis occurs remarkably early in the disease development process. Tumour cells extrude from the primary tumour, survive anchorage-independent apoptosis as free-floating cells or form spheroids, then spread across the peritoneal cavity where they proliferate and interact with mesothelial cells and adipocytes of the omentum. Due to the insidious nature of this disease, most patients with OC are diagnosed with advanced stages of the disease mainly due to intraperitoneal spread and often the presence of distant metastases (International Federation of Gynaecology and Obstetrics, FIGO stage III/IV disease) [6]. The early detection of OC remains challenging because clinically apparent symptoms only manifest during the disease's later 
stages. Metastases are associated with a poor prognosis where the typical overall survival rate ranges from weeks to months if untreated [7]. Only 15\% of patients are diagnosed at an early stage, whereas the majority of women are diagnosed with metastatic cancers ( $92 \%$ vs $29 \%$-year survival rate) [8]. Patients diagnosed with stage III or IV OC have a 5 -year survival rate of less than $25 \%$, including aggressive surgical resection and first-line chemotherapy drugs administration [9]. Therefore, conventional treatments such as debulking surgery and combination chemotherapy are rarely able to control the progression of the tumour, and relapses are frequent. Although up to $75 \%$ of patients achieve a good clinical response following initial therapy, almost all will ultimately relapse and eventually develop the chemotherapy-refractory disease. Consequently, the OC survival rate has not changed significantly despite decades of research [10]. Therefore, we need novel and effective therapeutic methods that would ensure beneficial long-term clinical outcomes for patients with OC. Metastasis from OC can occur via the transcoelomic, haematogenous, or lymphatic route. Transcoelomic metastasis being the most common is responsible for the highest morbidity and mortality rates among women with OC [11,12]. Malignant epithelial tumours account for $90 \%$ of all OC cases. Histopathology, immunohistochemistry and molecular genetic analysis are used to perform classification [13-15]. In samples obtained from patients, it is possible to distinguish high-grade serous carcinomas (HGSC), endometrioid carcinomas (EC), clear cell carcinomas (CCC), mucinous carcinomas (MC) and low-grade serous carcinoma (LGSC) [16,17]. Over two-thirds of OC cases account for HGSC. Immune signatures define a subgroup of HGSCs with a high percentage of infiltrating lymphocytes that have better survival outcomes. On the other hand, reactive stromal signatures with high levels of desmoplasmia, activated myofibroblasts, vascular endothelial cells and extracellular matrix remodelling is an indicator of the poorest prognosis [18-20].

$\mathrm{OC}$ is responsible for the dysregulation of the immune system in a multistep cooperative process. Stimulating the host to initiate the immune response against tumours requires the following: (1) a sufficient amount of effector T cells must be produced in the body to recognise tumour antigens effectively; (2) these cells must identify, present and infiltrate tumour tissue; (3) must overcome the inhibition of the tumour microenvironment (TME) on the immune network; (4) must directly identify tumour antigens and kill tumour cells; and (5) must maintain the activity of anti-tumour T cells for a long time [21,22]. While the TME tumour-associated immune cells may be initially involved in restricting tumour growth, these cells are also immunosuppressive and contribute to tumour progression due to their ability to block the host anti-tumour responses and drive the angiogenesis of the tumour. [23]. Myeloid leukocytes are the main components of the immune system supporting tumour expansion through secretion of growth factors, inhibition of anti-tumour T cells via the production of arginase and vascularisation [24]. For tumour growth and cancer dissemination tumour fibroblasts are responsible, while regulatory $\mathrm{T}$ cells cause immunosuppression of the host's system [25]. Tumour-associated macrophages (TAMs) adopt an alternative phenotype $\mathrm{M} 2$, characterised by enhanced tissue regenerative responses and local immune suppression [26]. OC cells secrete large amounts of IL-10, promoting differentiation of dendritic cells DC to CD14+CD1 a macrophage-like cell with reduced T-cell activation properties [27]. Although studies regarding immune cell profiles by histologic subtype are limited, researchers found that HGSC had the highest number of tissue cores stained with the pan leukocyte marker, CD45 and also more frequently FoxP3, CD25 or CD20 compared to other subtypes. Tumours with endometrioid histology (EC) had the second-highest and clear cell (CCC), as well as mucinous (MC), had the lowest percentages with infiltrates overall [28]. One mechanism by which several different types of immune cells are suppressed in the TME is through the production of indoleamine 2,3-dioxygenase (IDO) [29].

Currently, the first-line treatment regimen for OC patients is complete debulking surgery. Despite the fact that this type of surgery constitutes the basis for OC treatment, it is rarely sufficient alone for patients with advanced disease and must be combined with 
chemotherapy [30]. Increased understanding of OC biology and chemoresistance gained over the last few years led to the development of targeted molecular therapies improving the survival and increasing the quality of life in OC patients (VEGF-A antagonists, PARP inhibitors in $B R C A 1$ and $B R C A 2$ mutants). On the other hand, the majority of OC patients still do not have access to targeted molecular therapies that would be capable of controlling their disease [31]. One of the promising strategies overcoming non-specific activity and disease relapse is immunology engineering. Cell-based cancer immunotherapy represents a promising option for patients without access to treatment alternatives. This approach focuses on the use of the patient's immune system to destroy the OC cells and ideally on triggering an immunological memory response.

\section{What Is CAR?}

Chimeric antigen receptors (CARs) are recombinant antigen receptors located on $\mathrm{T}$ lymphocytes or other immune cells that redirect their specificity and functions [32]. The moieties used to bind to antigen fall in three general categories: (a) single-chain variable fragment (scFv) derived from antibodies; (b) antigen-binding fragment (Fab) selected from libraries or (c) nature ligands that engage their cognate receptor. The main rationale behind the use of CAR receptors in cancer immunotherapy is the rapid production of tumour-targeting $\mathrm{T}$ cells, bypassing the barriers and incremental kinetics of active immunisation [33]. The CAR-modified T cells acquire unique properties and act as 'living drugs' that may result in short-term, as well as long-term effects [34]. There are four generations of CARs used in clinical practice. The core structure of all four generations is an extracellular antigen recognition region with $\mathrm{scFv}$, which is responsible for immunogenicity, affinity and specificity [35]. With scFvs, CARs can target specific cells and trigger downstream signals. Fragments of scFvs derive from an antigen-specific monoclonal antibody (mAb) [36]. The receptor's extracellular domain originates from a cluster of differentiation CD4 and CD8. The transmembrane domain is usually derived from CD8, CD3- $\mathrm{f}$ (zeta), CD28 and intracellular tail including members of the tumour necrosis factor (TNF) receptor family, 4-1BB (CD137), OX-40 and CD27, has been incorporated to second and third generation [37]. The fourth generation of CARs is also called TRUCK T cells and was engineered to induce cytokines production, for example, IL-2, IL-12, IL-15 or granulocyte-macrophage colonystimulating factor (GM-CSF) [38]. The green fluorescent protein (GFP) is a protein that exhibits bright green fluorescence when exposed to light in the blue to ultraviolet range. It can be added to every generation of CAR in term to estimate its specificity to bind target antigen via fluorescence microscope. Figure 1 represents the structure of CARs.

Eshhar et al. designed structures that specifically recognise and respond to the antigen without signalisation of major histocompatibility complex (MHC) [39]. Unfortunately, firstgeneration CARs proved to be of limited clinical benefit because of failure in directing T-cell expansion upon repeated exposure to the antigen [40]. The 4-1BB ligand, CD137L is found on APCs (antigen-presenting cells) and binds to the 4-1BB superfamily, which is expressed on activated T Lymphocytes [41]. Savoldo et al. proposed incorporation of one stimulatory domain CD28 or 41BB to the second-generation CARs [42]. Third-generation CARs were formed by the incorporation of two or more costimulatory domains. On the other hand, their clinical effect in comparison to second-generation remains controversial $[43,44]$. The fourth-generation was developed to redirect $\mathrm{T}$ cells for universal cytokine killing, via the addition of an IL-12 expression cassette. IL-12 can accumulate in the target tissue and recruit a second wave of immune cells, e.g., NK cells, macrophages $[45,46]$. 


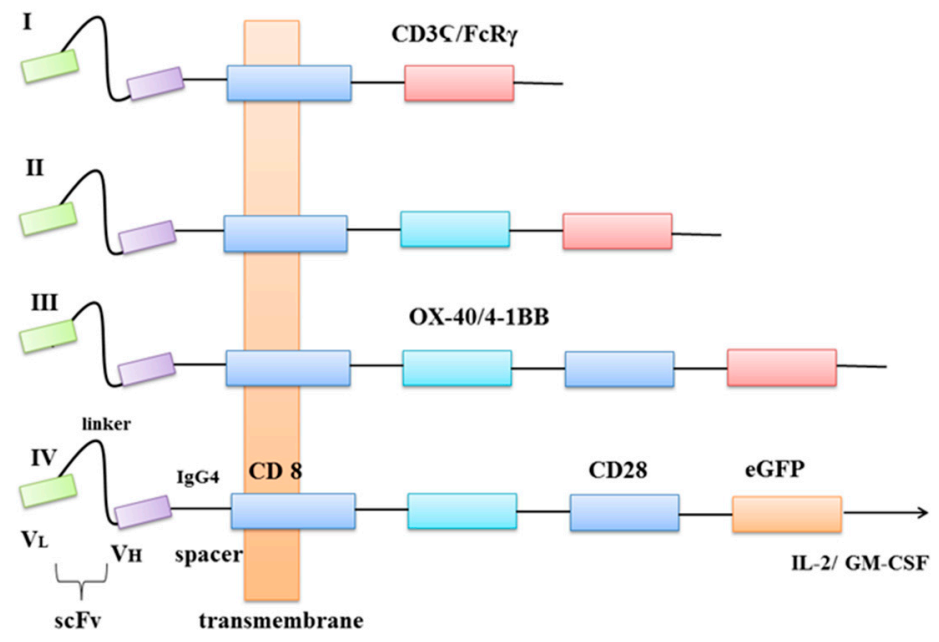

Figure 1. Four generations of CARs. $\mathrm{V}_{\mathrm{L}}$ - light chain variable domain, $\mathrm{V}_{\mathrm{H}}$ - heavy chain variable domain, $\mathrm{scFv}_{-}$- a single-chain variable fragment, spacer-protein fragments fused together, CD8 transmembrane protein, OX-40-also known as CD134 glycoprotein receptor, tumour necrosis factor receptor superfamily, 4-1BB-glycoprotein receptor tumour necrosis factor receptor superfamily, CD3S-protein complex and T-cell co-receptor that is involved in activating both the cytotoxic T cell and T helper cells, FcR $\gamma$-receptor for inducing phagocytosis, CD28-a protein that provides costimulatory signals, eGFP-enhanced green fluorescent protein, Il-2-interleukin 2 (cytokine), GM-CSF-granulocyte-macrophage colony-stimulating factor.

\section{How Are CARs Engineered?}

Scientists use several gene transfer methods to insert a specific gene into mice or human $\mathrm{T}$ lymphocytes. These methods differ in the expression levels and stability of mentioned CAR-T cells. In general, there are two main approaches in immune engineering: viral and non-viral [47]. Viral vectors have high infection rates; however, their production is costly and laborious. Moreover, there are also other challenges related to immunogenicity, carcinogenicity, low target cell specificity and inability to transfer large size genes. On the other hand, non-viral vectors can be relatively easy and cost-effectively produced. They are safe, can transfer large size genes and are less toxic. Their main disadvantages are low transfection efficiency and poor transgene expression [48]. Having considered the above, in this group, only the Sleeping Beauty (SB) transposon/transposase system with clustered regularly interspaced short palindromic repeats (CRISP/Cas9) has great potential [49]. Table 1 below lists the characteristics of different engineering methods of CARs.

Table 1. The characteristic of different engineering methods of CARs.

\begin{tabular}{|c|c|c|c|c|c|c|c|}
\hline $\begin{array}{l}\text { Genetic } \\
\text { Approach }\end{array}$ & Methods & Structure & Study & Target & Advantages & Disadvantages & Source \\
\hline \multirow{3}{*}{ Viral } & $\begin{array}{l}\text { Retroviral } \\
\text { vectors }\end{array}$ & ssRNA & in vivo & $\begin{array}{l}\text { only } \\
\text { mitosis }\end{array}$ & substitutability $\uparrow$ & $\begin{array}{c}\text { insertional } \\
\text { mutagenesis } \uparrow \\
\text { titre vector } \\
\text { production } \uparrow\end{array}$ & [50] \\
\hline & $\begin{array}{l}\text { Lentiviral } \\
\text { vectors }\end{array}$ & ssRNA & in vivo & entire cycle & $\begin{array}{c}\text { integration } \uparrow \\
\text { risk of } \\
\text { insertional } \\
\text { mutagenesis } \\
\downarrow\end{array}$ & $\begin{array}{l}\text { possible insertional } \\
\text { mutagenesis } \uparrow \\
\text { presence of regulatory } \\
\text { proteins in the } \\
\text { packaging construct } \\
\text { transient expression of } \\
\text { the transgene with } \\
\text { integration-defective } \\
\text { vector } \uparrow\end{array}$ & [51] \\
\hline & Adenoviruses & dsDNA & in vivo & entire cycle & toxicity $\downarrow$ & integrity $\downarrow$ & {$[52]$} \\
\hline
\end{tabular}


Table 1. Cont.

\begin{tabular}{|c|c|c|c|c|c|c|c|}
\hline $\begin{array}{c}\text { Genetic } \\
\text { Approach }\end{array}$ & Methods & Structure & Study & Target & Advantages & Disadvantages & Source \\
\hline & $\begin{array}{c}\text { Adeno- } \\
\text { associated } \\
\text { viral vectors }\end{array}$ & ssDNA & in vivo & entire cycle & $\begin{array}{c}\text { infection } \\
\text { efficiency } \uparrow \\
\text { gene } \\
\text { expression } \uparrow\end{array}$ & $\begin{array}{c}\text { internalisation } \downarrow \\
\text { endosomal } \\
\text { trafficking } \downarrow \\
\text { nuclear import } \downarrow\end{array}$ & [53] \\
\hline \multirow{3}{*}{ Nonviral } & $\begin{array}{l}\text { Liposome- } \\
\text { mediated } \\
\text { gene transfer }\end{array}$ & $\begin{array}{c}\text { lipid } \\
\text { n-layer }\end{array}$ & in vitro & entire cycle & $\begin{array}{c}\text { condensation } \\
\text { of DNA } \uparrow \\
\text { infection } \\
\text { efficiency } \uparrow\end{array}$ & $\begin{array}{l}\text { transfection } \\
\text { efficiency } \downarrow\end{array}$ & [54] \\
\hline & $\begin{array}{l}\text { Messenger } \\
\text { RNA- } \\
\text { mediated } \\
\text { gene } \\
\text { transduction }\end{array}$ & ssRNA & in vitro & entire cycle & $\begin{array}{c}\text { insertional } \\
\text { mutations } \downarrow \\
\text { potential } \\
\text { malignant } \\
\text { transforma- } \\
\text { tion/ } \\
\text { genotoxicity } \\
\downarrow \\
\text { off-tumour, } \\
\text { on-target side } \\
\text { effects } \downarrow\end{array}$ & $\begin{array}{c}\text { instable, } \\
\text { non-biocompatible } \downarrow \\
\text { low biodegradability, } \\
\text { low efficacy } \downarrow \\
\text { toxicity at high dose, } \\
\text { difficult preparation, } \\
\text { low transformation } \\
\text { efficiency } \downarrow\end{array}$ & {$[46,55]$} \\
\hline & $\begin{array}{l}\text { Sleeping } \\
\text { Beauty } \\
\text { transpo- } \\
\text { son/transposase } \\
\text { system }\end{array}$ & $\begin{array}{l}\text { plasmid- } \\
\text { plasmid }\end{array}$ & in vivo & entire cycle & integration $\uparrow$ & $\begin{array}{c}\text { insertional } \\
\text { mutagenesis } \downarrow\end{array}$ & [50] \\
\hline
\end{tabular}

A CAR intervention example of a mechanism in patients is shown in Figure 2.

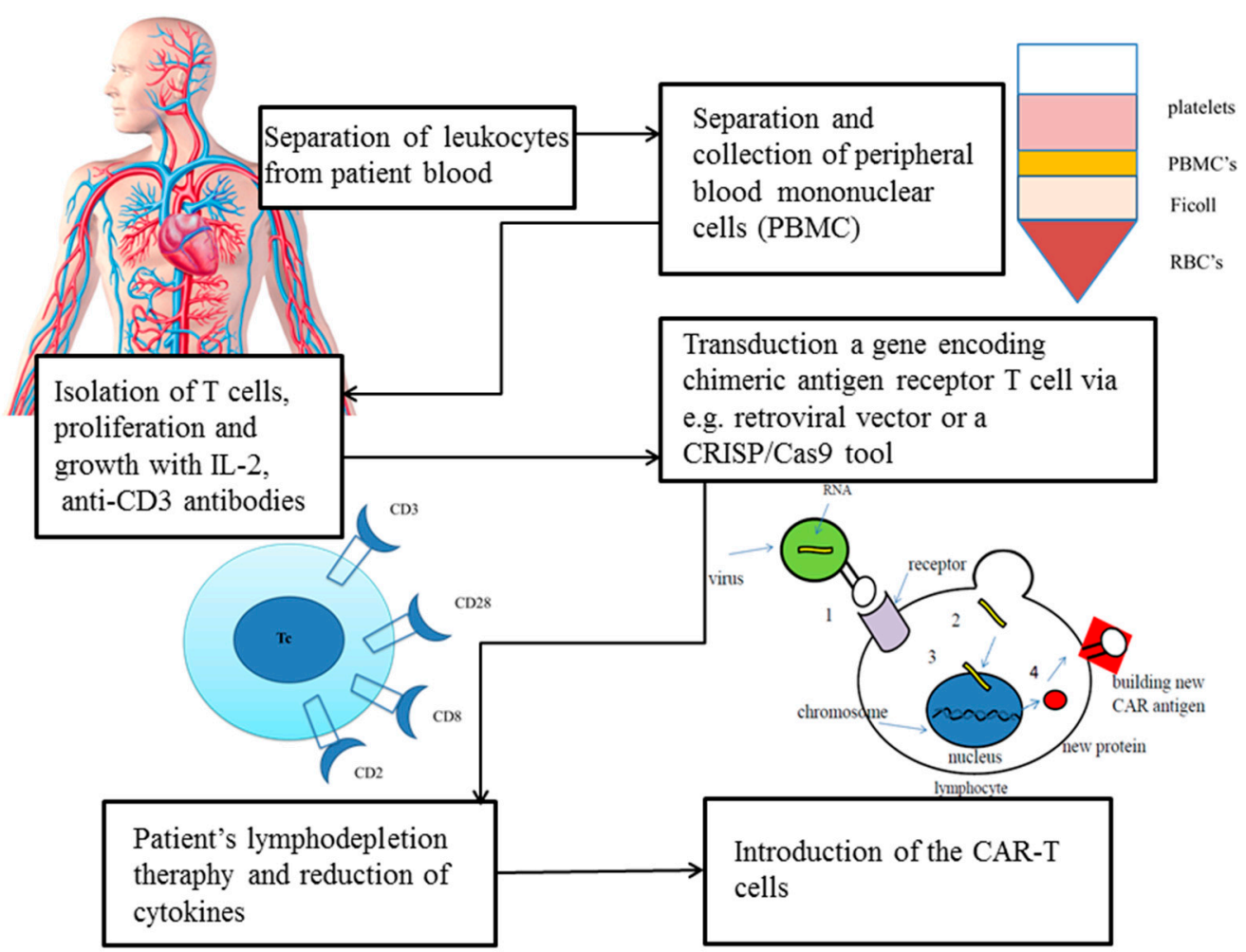

Figure 2. Transduction of a gene encoding a CAR in T cell via a retroviral vector or a CRISP/Cas9 tool [56]. 
The SB transposon system requires only two components: transposon DNA and transposase enzyme [57]. The most efficient way to deliver selected components into the target cell is the classical two-plasmid configuration: one for SB transposase and other for an artificial transposon flanked via terminal inverted repeats (TIR) on both sides of a vector [58]. This system also takes into account the origin of replication component and antibiotic resistance gene of choice. To setup transposon into the target cell, transfection or electroporation can be used [57]. To eliminate toxicity effect and decrease the immunogenic reaction of DNA transfection, it is best to use the current state-of-the-art delivery methods, messengers mRNA or minicircle DNA (MC) [59]. The SB's production disadvantages are poor protein stability, low solubility and aggregation properties; however, incorporation of two mutations I212S and C176S into SB100X transposase improves these features [60]. A recent study indicates that using a catalytically inactive Cas9 (dCas9) with single-guide RNA approach may facilitate genetic material insertion into a genome [61]. Cas9 is a dual RNA-guided DNA endonuclease enzyme that uses base pairing to recognise and cleave target DNA with complementarity to the guide RNA, such as invading bacteriophage DNA or plasmid DNA [62]. Tethering the transposase toward a target that is overexpressed in the human genome dramatically increases the number of possible attach points and thus induces chances of targeted transposition with a flexible and easy-to-use RNA-guided system [63]. Pilot studies have indicated that SB is a safe and effective tool to manufacture therapeutic CAR-T cells in cancers [64-67].

\section{In Vitro and In Vivo Studies}

In recent years, CARs proved to be particularly effective in patients with haematological cancers $[68,69]$. Solid tumours, however, remain challenging because of their histopathological structure, aberrant vasculature and extensive vascular leakage [70]. In the OC (solid malignancies) therapy with the CAR-T cells, the key issues are lack of target antigen specificity, intrinsic target antigen heterogeneity, an immunosuppressive TME, expression of immune checkpoint molecules, ineffective intracellular trafficking/infiltration and low persistence.

The critical issue related to CAR-T-cell therapy in solid tumours is the identification of corresponding tumour target antigens absent or expressed at remarkably low levels in healthy tissue, most notably in vital organs. This problem is further amplified because each particular CAR-T cell only needs to recognise a few receptors on the target cell for full activation to occur. Selecting an ideal target antigen (i.e., overexpressed on tumour cells and with minimal or no expression on healthy tissues) will eliminate off-target effects and associated toxicity [71-73]. Yet another issue relates to the immunosuppressive TME. TME contains various interacting components, including tumour cells, immune cells, stromal cells, chemokines, cytokines and extracellular matrix. In solid tumours, TME exhibits strong immunosuppressive effects due to the recruitment of tumour-associated macrophages (TAMs), cancer-associated fibroblasts (CAFs), myeloid-derived suppressor cells (MDSCs) and regulatory T cells (Treg), and the production of immunosuppressive cytokines and soluble factors (e.g., IL-10, VEGF, TGF $\beta$, indoleamine 2,3-dioxygenase and adenosine) [74].

A hypoxic, low $\mathrm{pH}$ intrinsic microenvironment and the activated inhibitory pathways appear to be problematic when it comes to T-cell trafficking and T-cell infiltration into tumour sites [75]. These adaptive survival-oriented cancer changes contribute to the induction of selectively enhanced permeability and retention of lipid particles and macromolecular substances. Therefore, in a search for a successful solid tumour therapy using CARs the specific cell surface antigens identification is crucial. To reduce 'on-target, off-tumour toxicity', an idea of introducing a regulated suicide gene into CARs such as the HSV-TK (herpes simplex virus I-derived thymidine kinase) or iCasp9 (caspase 9) has been proposed. Both, the T cells with HSV-TK and iCasp9 genes prevent alloreactivity, exhibit low potential immunogenicity and no acute toxicity without compromising their functional and phenotypic characteristics [76]. 
The cell surface antigens targeted by CARs include proteins, carbohydrates and glycolipids. In in vivo and in vitro studies most common antigens targeted by CARs in OC cells include MUC16, folate receptor- $\alpha(\mathrm{FR} \alpha)$, mesothelin and HER2 (Table 2).

Table 2. Antigenic targets being exploited for CAR-T-cell therapy in OC treatment.

\begin{tabular}{|c|c|c|c|c|c|c|c|}
\hline $\begin{array}{c}\text { Target } \\
\text { Antigen }\end{array}$ & Cells & Gene Transfer & $\begin{array}{l}\text { Intervention/ } \\
\text { Monitoring }\end{array}$ & Study & Studied Material & Outcomes & Source \\
\hline MSLN & $\mathrm{T} / \mathrm{NK}$ & $\begin{array}{c}\text { messenger } \\
\text { RNA- } \\
\text { mediated gene } \\
\text { transduction }\end{array}$ & $\begin{array}{l}\text { i.p. } 1 \times 10^{8} \text { cells } / \\
\text { up to } 6 \text { weeks }\end{array}$ & in vivo & $\begin{array}{c}\text { Defb29 } \\
\text { Vegf-luc/Hmeso } \\
\text { Platinum resistant } \\
\text { OC }\end{array}$ & $\begin{array}{l}\downarrow \text { tumour burdens } \\
\uparrow \text { mice survival }\end{array}$ & [77] \\
\hline $\begin{array}{l}\text { CD24 } \\
\text { MSLN }\end{array}$ & NK-29 & $\begin{array}{l}\text { lentiviral } \\
\text { transduction }\end{array}$ & $5 \times 10^{4}$ cells $/ 24 \mathrm{~h}$ & in vitro & $\begin{array}{c}\text { A2780, OVCAR3, } \\
\text { SKOV3, } \\
\text { Primary OC }\end{array}$ & $\uparrow$ cytotoxicity & [78] \\
\hline MSLN & NK & $\begin{array}{l}\text { transposon } \\
\text { vector }\end{array}$ & $\begin{array}{l}\text { i.p. } 1.5 \times 10^{7} \text { cells / } \\
\text { up to } 7 \text { weeks }\end{array}$ & in vivo & $\begin{array}{l}\text { A1847, } \\
\text { MA } 148\end{array}$ & $\begin{array}{c}\text { 个inhibition of } \\
\text { tumour growth } \\
\uparrow \text { survival }\end{array}$ & [79] \\
\hline ANXA2 & $\mathrm{T}$ & $\begin{array}{l}\text { lentiviral } \\
\text { vector }\end{array}$ & $\begin{array}{l}\text { i.p. } 5 \times 10^{6} \text { cells } / \\
\text { up to } 5 \text { days }\end{array}$ & in vivo & IGROV-1, SKOV3 & $\begin{array}{c}\uparrow \text { cytokine release } \\
\uparrow \text { cytotoxicity } \\
\uparrow \text { survival } \\
\downarrow \text { tumour burdens }\end{array}$ & {$[80]$} \\
\hline $\mathrm{FR} \alpha$ & NK & $\begin{array}{l}\text { lentiviral } \\
\text { vector }\end{array}$ & $\begin{array}{l}\text { i.p. } 1 \times 10^{6} \text { cells / } \\
\text { up to } 10 \text { days }\end{array}$ & in vivo & $\begin{array}{l}\text { SKOV3, A2780, } \\
\text { HTC116, A431 }\end{array}$ & $\begin{array}{c}\text { 个elimination of } \\
\text { cancer cells } \\
\uparrow \text { survival }\end{array}$ & [81] \\
\hline CXCR1 & NK & $\begin{array}{c}\text { mRNA } \\
\text { transfection }\end{array}$ & $\begin{array}{c}\text { i.v. } 5 \times 10^{6} \\
\text { cells } / \text { twice a } \\
\text { week } / 2 \text { weeks }\end{array}$ & in vivo & $\begin{array}{c}\text { SKOV3, CaOV3, } \\
\text { SW626 }\end{array}$ & $\begin{array}{c}\text { ascites generation } \downarrow \\
\downarrow \text { tumour cells in } \\
\text { ascites samples } \\
\text { complete metabolic } \\
\text { response } \\
\uparrow \text { survival }\end{array}$ & [82] \\
\hline $\begin{array}{l}\text { PDL1 } \\
\text { MUC16 }\end{array}$ & $\mathrm{T}$ & $\begin{array}{l}\text { lentiviral } \\
\text { infection }\end{array}$ & $\begin{array}{l}\text { i.p. } 1 \times 10^{6} \text { cells } / \\
\text { up to } 4 \text { weeks }\end{array}$ & in vivo & SKOV3 & $\begin{array}{l}\uparrow \mathrm{IL}-2, \mathrm{IFN}-\gamma, \\
\text { TNF- } \alpha \\
\uparrow \text { regression of } \\
\text { ovarian cells } \\
\uparrow \text { survival }\end{array}$ & [83] \\
\hline L1-CAM & Tcm & $\begin{array}{l}\text { lentiviral } \\
\text { vector }\end{array}$ & $\begin{array}{c}\text { i.p. } 5 \times 10^{6} / \text { up to } \\
17 \text { weeks }\end{array}$ & in vivo & $\begin{array}{c}\text { CAOV-3, } \\
\text { OVCAR-3, SKOV-3, } \\
\text { MADH2780, A2780 }\end{array}$ & $\begin{array}{c}\text { regression of } \\
\text { tumours in the } \\
\text { peritoneal cavity } \\
\text { and massive ascites }\end{array}$ & [84] \\
\hline $\begin{array}{l}\text { HER2/ } \\
\text { neu }\end{array}$ & $\mathrm{T}$ & $\begin{array}{l}\text { lentiviral } \\
\text { vector }\end{array}$ & 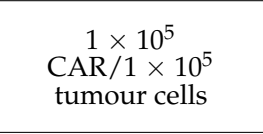 & in vitro & $\begin{array}{c}\text { SKOV3, OVCAR3, } \\
\text { A2780, } \\
\text { A1847 }\end{array}$ & $\begin{array}{c}\uparrow \text { expression of } \\
\text { CARs } \\
\uparrow \text { cytotoxicity } \\
\downarrow \text { tumour cells }\end{array}$ & [85] \\
\hline $\mathrm{FR} \alpha$ & $\mathrm{T}$ & $\begin{array}{l}\text { retroviral } \\
\text { vector }\end{array}$ & $\begin{array}{l}\text { i.v. up to } 5 \times 10^{5} \\
\text { cells } / 48 \mathrm{~h}\end{array}$ & in vivo & $\begin{array}{l}14 \text { patients with } \\
\text { recurrent, resected } \\
\text { recurrent, or } \\
\text { residual epithelial } \\
\text { FR+ ovarian cancer }\end{array}$ & $\begin{array}{l}\text { The treatment was } \\
\text { well tolerated, } \\
\text { but no antitumour } \\
\text { effect was } \\
\text { observed. }\end{array}$ & {$[40]$} \\
\hline $\mathrm{FR} \alpha$ & $\mathrm{T}$ & $\begin{array}{l}\text { lentiviral } \\
\text { vector }\end{array}$ & $\begin{array}{l}\text { i.v. up to } 1 \times 10^{6} \\
\text { cells } / 4 \text { weeks }\end{array}$ & in vivo & $\begin{array}{l}\text { SKOV-3, OVCAR3, } \\
\text { A1847, C30, PEO-1 }\end{array}$ & $\begin{array}{l}\text { tumour regression } \\
\text { T-cell persistence } \downarrow\end{array}$ & [86] \\
\hline FSHR & $\mathrm{T}$ & $\begin{array}{l}\text { retroviral } \\
\text { vector }\end{array}$ & $\begin{array}{c}\text { i.p. } 2 \text { injections up } \\
\text { to } 1.5 \times 10^{6} \\
\text { cells / up to } 50 \text { days }\end{array}$ & in vivo & $\begin{array}{c}\text { mouse xenografts } \\
\text { OVCAR-3, CaOV3, } \\
\text { RNG1, OVTOKO } \\
\text { and TOV-21G }\end{array}$ & $\begin{array}{l}\text { increased survival } \\
\text { no toxicity }\end{array}$ & [87] \\
\hline $5 \mathrm{~T} 4$ & $\mathrm{~T}$ & $\begin{array}{l}\text { lentiviral } \\
\text { vector }\end{array}$ & $\begin{array}{l}\text { i.p. up to } 6 \times 10^{4} \\
\text { cells } / 100 \text { days }\end{array}$ & in vivo & SKOV-3 & $\begin{array}{l}\text { 5T4-specific CAR } \\
\text { can recognise and } \\
\text { respond } \\
\text { physiologically } \\
\text { to autologous } \\
\text { tumour cells }\end{array}$ & [88] \\
\hline TAG72 & & $\begin{array}{l}\text { lentiviral } \\
\text { vector }\end{array}$ & $\begin{array}{c}\text { i.p.,i.v. } 5 \times 10^{6} \\
\text { cells/up to } 8 \text { weeks }\end{array}$ & in vivo & $\begin{array}{c}\text { mouse xenografts } \\
\text { SKOV-3, OVCAR-3, } \\
\text { OVCAR-3 }\end{array}$ & $\begin{array}{l}\downarrow \text { tumour growth } \\
\uparrow \text { survival }\end{array}$ & [89] \\
\hline
\end{tabular}

MSLN-mesothelin, CD24-signal transducer sialoglycoprotein, ANXA2-annexin 2, FR $\alpha$-folate receptor $\alpha$, CXCR1-chemokine receptor 1, PDL1 - programmed death-ligand 1, MUC16-mucin 16, L1-CAM-L1 transmembrane protein family, HER2/neu-receptor tyrosineprotein kinase erbB-2, FSHR — follicle-stimulating hormone receptor, 5T4 — trophoblast glycoprotein (TPBG), TAG72-tumour-associated glycoprotein 72 . 
Mesothelin (MSLN), a cell surface glycoprotein, is generally expressed in mesothelial cells lining the pleura, peritoneum (minimally on the epithelial cells of the ovaries and fallopian tubes) and pericardium, however highly expressed in many tumour cells, including OC; its soluble form can also be found in the bloodstream of OC patients [90]. Studies have identified MSLN as a promising tumour antigen in OC as it is overexpressed in over $75 \%$ of HGSOC tumours [91]. A number of agents including CAR T-cells targeting MSLN have been developed, and are currently being investigated. There were also other preclinical studies conducted focusing on the use of mesothelin-based CAR-T cells in subcutaneous or in situ mouse models of mesothelioma, ovarian cancer and lung cancer transplantation [77-79].

Recent studies reveal that annexin 2 (ANXA2) has been detected in OC. Overexpression of ANXA2 mediates extracellular matrix degradation and neovascularisation by the production of plasmin and correlates with invasion and metastasis [80]. Lately, it has been suggested that natural killer (NK) cells may be better chimeric antigen receptor drivers than $\mathrm{T}$ cells because of their favourable innate features, such as direct recognition and elimination of tumour cells [79]. To overcome 'on-target off-tumour' cytotoxicity, the dual-target CARs may be a better choice [92]. It has been shown that dual CARs are related to the longer survival time of mice up to two times when compared to single CAR groups and control group (80 vs. 40 days) [83].

The alpha isoform, folate receptor $\alpha(\mathrm{FR} \alpha)$, also known as gene FOLR1 or folate binding protein (FBP), is a glycosylphosphatidylinositol (GPI)-anchored membrane protein that binds folic acid with high affinity and transports folate (vitamin B9) by receptormediated endocytosis. FR $\alpha$ has been reported to be overexpressed in solid tumours such as OC, precisely $90 \%$, but has restricted expression in normal cells. From the perspective of OC, where increasing levels of tissue FR are associated with tumour progression, it is an attractive therapeutic target [93]. Moreover, FR $\alpha$ expression is not affected by any earlier treatment attempts using chemotherapy. Having considered that, folate receptor $\alpha$ is ideal for a tumour antigen in targeted treatments of OC [81]. The first team that constructed CAR-T cells targeting FR $\alpha$ and used the CAR-T cells to treat OC was Kershaw et al.- the murine MOv18 scFv was used and a signalling domain of the Fc receptor $\gamma$ chain [40]. It was later demonstrated that CAR-T cells targeting FR $\alpha$ is safe to administer, despite not showing the desired therapeutic effects. Ao at al. further verified that the anti-FR $\alpha$ CARs redirect NK-92 cells with specific anti-tumour activity, and the third-generation antiFR $\alpha$ CAR-engineered NK-92 cells display more potent cytotoxicity against FR $\alpha$-positive OC [81]. Song et al. investigated the coupling of the FR $\alpha$-specific site $\mathrm{ScFv}$ (MOv19) with the T-cell receptor $\mathrm{CD} 3 \zeta$ chain signalling module alone (MOv19- $\zeta$ ) or in combination with the CD137 (4-1BB) costimulatory motif in tandem (MOv19-BB $\zeta$ ). In the co-culture process of $\mathrm{FR} \alpha(+)$ OC cells, MOv19- $\zeta$ and $\mathrm{MOv} 19-\mathrm{BB} \zeta$ may result in increased secretion of various inflammatory factors, such as IFN- $\gamma$, IL-2, TNF- $\alpha$ and IL-4. Moreover, in intraperitoneal, subcutaneous and lung metastases in FR $\alpha(+)$ animal models, the use of MOv19-BB $\zeta$ CAR-T cells have shown positive therapeutic effects [86].

CXCR1 (interleukin-8 receptor alpha [IL-8RA]) is the G protein-coupled receptor that binds IL-8 with high affinity. The proinflammatory cytokine IL-8 expression produced by tumour tissues to recruit leukocytes is substantially higher in a wide range of tumour types, as well as in OC $[94,95]$. Whilding et al. showed that IL-8 is actually produced by many $\alpha \mathrm{v} \beta 6$-positive cancer cell lines, among them SKOV3, and is present in the circulation of mice engrafted with various tumour xenografts expressing this integrin [96]. It has been reported that circulating IL-8 levels correlate with disease severity and prognosis in a number of solid tumours, where it is involved in a wide range of pathological functions, including angiogenesis, support of tumour stem cells survival and immunosuppressive myeloid cells recruitment [97]. CXCR1- and CXCR2-containing CAR-T cells showed increased migration towards IL-8 and conditioned media containing this chemokine. Furthermore, $\mathrm{T}$ cells that co-expressed CAR A20-28z and CXCR2 increased tumour control in vivo compared to CAR T cells deprived of this chemokine receptor, without accompanying 
toxicity [96]. Ng et al. demonstrated that expression of the IL-8 receptor CXCR1 to match CAR-NK cells to a chemokine secreted by the tumour facilitated increased migration and infiltration into the tumour and improved the anti-tumour responses of the immune effector cells in vivo [82]. Having considered various studies results, it seems that PD-1 is another ideal target for CAR T therapy. Programmed cell death-1 (PD-1), also called programmed cell death-ligand 1 inhibitor, is an immune checkpoint immunomodulator highly expressed on antigen-presenting cells, hepatocytes and tumours. Interaction with programmed cell death-1 results in inhibition of antigen-specific responses on T cells, B cells and macrophages. PD-1 belongs to the CD28/cytotoxic T lymphocyte-associated antigen-4(CTLA-4) family [98]. Antibodies that block PD-1/PD-L1 interaction reduce signalling between co-inhibitory molecules. It is also known that $\mathrm{T}$ cells are able to secrete cytokines, such as IL-10 and IFN- $\gamma$, to induce the generation of a CTLA ligand on OC cells, e.g., PD-1. At the same time, PD-1 induces expression and binds to inhibitory receptors on the surface of $\mathrm{T}$ cells. This reduces the anti-activity of effector $\mathrm{T}$ cells and directs $\mathrm{T}$ cells ${ }^{\prime}$ movement to sites of inflammation. Sometimes, it results in $\mathrm{T}$ cells being unable to avoid the immune response [99]. Yet another experiment (on mice with melanoma) revealed that the $T$ cells escape from immune surveillance is suppressed after upregulation of the PDL-1 expression in the tumour microenvironment (TME). The T-cell infiltration could, however, be made considerably greater. In order to achieve that, intraperitoneal injection of a PD-1 antibody is required as this procedure aims to block the PD-1 pathway [100]. Another study where patients with low PDL-1 expression were compared to patients with high PDL-1 expression revealed that the five-year survival rate is considerably greater in the former group [101].

From a clinical perspective, the most crucial peripheral checkpoint inhibitor pathway exploited by tumour cells within the TME identified to date is the interaction between the PD-1 receptor on T cells with its programmed death-ligand 1 (PD-L1) and programmed death-ligand 2 (PD-L2) on tumour cells. Increased expression of PD-L1 on T4 CAR T cells occurred when these cells were in culture with OC cells. By contrast, EOC cell lines exhibited increased PD-L1 expression after chemotherapy treatment [102].

A particular class of targets that has had limited exploration in CARs against solid tumours are glycoepitopes. External glycosylation in cancer can be initiated via dysregulation of glycosyltransferases, altering both the function and molecular profile of tumour cells. It is generally agreed that abnormal glycosylation of tumour cells leads to creation of new connections with immune cells that actively suppress anti-tumour immunity. Therefore, as tumour-specific glycosylation patterns determine the immune suppressive nature of tumours, their interactions with endogenous carbohydrate-binding proteins (lectins) could be considered as new immune checkpoints to be targeted by immunotherapy [103].

Mucin 16 (MUC16, cancer antigen 125, CA125) is mainly overexpressed in ovarian cancer (above $80 \%$ ) with the shedding of antigens in a soluble form or membrane-bound form that can suppress humoral immunity, especially antibody-dependent cytotoxicity (ADCC). CA125, encoded by MUC16, is a well-known circulating marker of early stage disease that is monitored in the clinical course of OC patients. MUC16 is a macromolecule transmembrane mucin consisting of a single membrane-spanning domain, a cytoplasmic tail, an extensive $\mathrm{N}$-terminal domain and a tandem repeat sequence, with CA125 antigen in the MUC16 tandem repeat. The interaction between MUC16 and MSLN contributes to peritumoral adhesion and spheroid formation, thus providing a targeting strategy that is being developed to reduce peritumoral metastasis and facilitate other therapies [104]. MUC16-CAR-T cells injected intravenously or intraperitoneally are able to delay OC's progression or altogether remove tumours in mouse tumour-bearing models. Therefore, again it seems that MUC16 is an ideal antigenic target for CAR molecules [83].

L1 cell adhesion molecule (L1-CAM) is a 200-220 kDa transmembrane glycoprotein of the immunoglobulin (Ig) superfamily. It plays a vital role in neuronal cell adhesion and migration, such as neurite outgrowth guidance, axon binding, myelination, synaptogenesis and long-term potentiation. The abnormal expression of L1-CAM protein is strongly 
correlated with the aggressive behaviour of many human malignancies. Mechanistic studies showed that forcibly altered L1-CAM expression significantly alters cell properties, including invasion, migration, proliferation and chemoresistance [105]. Hong et al. have shown that the L1-CAM is highly over-expressed in ovarian cancer, while absent in normal ovaries [84], and that its expression on tumours is also associated with poor clinical outcome [106]. The same team demonstrated that L1-CAM-specific CAR T cells allow considerable control of solid tumour growth in an in vivo ovarian cancer xenograft model that exhibited clinically significant manifestations of widespread tumour metastasis in the peritoneal cavity and massive ascites.

Human epidermal growth factor receptor 2 (HER2; also called Her-2/neu or ErbB2) is a member of the transmembrane epidermal growth factor receptor family and is one of the most studied TAAs for cancer immunotherapy. HER2 is a proto-oncogene and plays a vital role in the pathogenesis and clinical process of various tumours. In vitro and animal experiments have clearly shown that gene amplification and protein overexpression of HER2/neu play a key role in tumorigenic transformation and development of tumours [107]. Subsequent studies have shown that HER2/neu gene amplification and overexpression are associated with OC while protein expression in normal tissues is negative or very low. Overexpressed HER2/neu proteins make tumours more aggressive and are independent risk factors for poor prognosis in these cancer patients [108]. Sun et al. constructed and evaluated a novel anti-HER2 chA21 scFv-based CAR. The results of this study show that novel chA21 scFv-based, HER2-specific CAR T cells not only recognised and killed HER2+ breast and ovarian cancer cells ex vivo but also induced regression of experimental breast cancer in vivo. The data support further exploration of the HER2 CAR T-cell therapy for HER2-expressing cancers [85]. At present, HER2-specific CAR-T-cell therapy has shown good therapeutic potential in the preclinical stage. However, HER2-CAR-T-cell treatment in OC is still in the clinical experimental stage.

The follicle-stimulating hormone receptor (FSHR) is thought to be selectively expressed in women in ovarian granulosa cells and at low levels in the ovarian endothelium. This surface antigen is expressed in $50-70 \%$ of serous OCs, although its expression in other histological types of OC remains unknown. Perales-Puchalt et al. revealed that in immunocompetent mice growing syngeneic, orthotopic and aggressive ovarian tumours, fully murine FSHR-targeted T cells increased the survival without any measurable toxicity. In that study, chimeric receptors enhanced endogenous tumour-reactive $\mathrm{T}$ cells' ability to abrogate malignant progression upon adoptive transfer into naive recipients subsequently challenged with the same tumour [87].

There is a promising solution to prevent systemic toxicity-it requires to combine tumour-specific protein, e.g., NKG2D linked to IL-2. Interleukin-2 is a cytokine from the cytokine-receptor $\gamma$-chain family with many potentially useful functions including stimulation of T cells, NK cells and immunoglobulins [109]. NKG2D is a transmembrane protein belonging to the NKG2 family of C-type lectin-like receptors. The NKG2D proteins are stress-induced self-proteins entirely absent or present only at low levels on normal cells ${ }^{\prime}$ surface. Still, they become overexpressed by infected, transformed, senescent and stressed cells [110]. Kang et al. showed that TC-1 tumour-bearing mice treated with a therapeutic HPV type 16E7 DNA vaccine and then given the DNA construct encoding the chimeric NKG2D-Fc-IL2 protein demonstrated reduced tumour mass growth and prolonged survival. Specific delivery of IL-2 with the NKG2D-Fc system led to the expansion of tumour antigen-specific CD8+ T cells at the tumour loci and an improved therapeutic anti-tumour effect generated by the therapeutic DNA HPV vaccine [111]. Other molecules that combine with the NKG2D-Fc system could be IL-12, IL-15 or GM-CSF [112].

Wang et al. designed a novel anti-uPAR CAR consisting of antigen recognition domain using a natural amino-terminal fragment, a part of the A chain of uPA instead of scFv to construct the third-generation CAR (ATF-CAR) T cells against OC cells in vitro [113]. UPAR (urokinase plasminogen activator receptor) is a receptor for UPA involved in the conversion of plasminogen to plasmin, which degrades the extracellular matrix (ECM) 
during tumour migration and metastasis. uPAR also affects other signals which induce tumorigenesis, tumour proliferation and adhesion and tumour dormancy and reactivation in OC [114]. It is worth mentioning that uPAR expression in healthy cells is relatively rare and focuses upon healing and tissue remodelling process and inflammatory response in some macrophages, endothelial cells and respiratory cells, which make this receptor an excellence choice for CAR development [115]. At a ratio of 10:1 ATF-CAR T cells exhibited significant lysis cytotoxicity against uPAR-positive cells SKOV3, HO8910, C13K and ES-2. Moreover, they were shown to produce higher levels of Th1 cytokines [113].

The 5T4 oncofoetal antigen was first identified during a search for surface molecules shared between human trophoblasts and cancer cells with the rationale that they may function to allow survival of the foetus as a semiallograft in the mother or a tumour in its host. The $5 \mathrm{~T} 4$ is a $72-\mathrm{kDa}$ transmembrane protein expressed on the placenta and a wide range of human carcinomas [116]. The 5T4 is known to be highly expressed in OC, and its expression correlates with more advanced stages of disease (FIGO stages III and IV) and with poorly differentiated tumours. Patients whose tumours express 5T4 seem to have a worse progression-free and overall survival [117]. Owens et al. has shown that polyclonal lymphocytes isolated from the peripheral blood of patients with OC, can be redirected to target tumour cells expressing 5T4 effectively. Co-culture of CAR T cells with matched autologous tumour disaggregates resulted in antigen-specific secretion of IFN- $\gamma$. Assessment of anti-5T4 CAR T cells' efficacy in a mouse model allowed to discover a therapeutic benefit against the established ovarian tumours [88].

Several researchers attempted to combine CAR intervention with other therapies. Wahba et al. showed that in vivo paclitaxel synergises with ErbB-targeted CAR T cells (T4) [102]. The ErbB family of proteins contains four receptor tyrosine kinases, structurally related to the epidermal growth factor receptor (EGFR) and via PI3-K/AKT pathway leads to increased cell proliferation and inhibition of apoptosis. Paclitaxel binds to the h-tubulin subunit and stabilises the microtubules, resulting in disruption of normal microtubule dynamics during cell division. Failure of microtubule separation during the G2/M phase blocks cell mitosis and results in apoptosis. DNA damage caused by chemotherapy leads to cleavage and activation of intracellular caspases, initiating a proteolytic cascade and eventually cell death. Reversal of apoptosis can be achieved using the pan-caspase inhibitor carbobenzoxy-valyl-alanyl-aspartyl-[O-methyl]-fluoromethylketone (Z-VAD), which binds to caspase proteases irreversibly, preventing the initiation of the proteolytic cascade. In their study treating ovarian tumour cells with chemotherapy and Z-VAD resulted in a reversal of the anti-tumour activity observed following chemotherapy treatment. When Z-VAD was used with chemotherapy and T4 cells, there was a partial, yet significant reversal in the reduction seen in tumour cell viability. The reversal was not complete, suggesting that caspase induction, or indeed apoptosis, was not the sole mechanism but was definitely contributing to the combination therapy's synergistic effect. Mannose-6phosphate receptor-mediated autophagy and the arrest of the cell cycle in G2/M have also shown to be induced by chemotherapy and significantly contributing to the synergy [102].

\section{Clinical Trials}

Using CARs has resulted in successful outcomes in hematopoietic malignancies and inspired introduction of similar strategies to treat solid tumours [118-120]. Despite encouraging results of in vitro and in vivo studies, the solid cancer methods of treatment are not developed enough to achieve the desired results. There are a few studies that describe the potential application of CARs in the treatment strategy of patients with OC. In early clinical trials of first-generation CAR T cells for OC, safety and therapeutic efficacy were difficult to be determined because of the aforementioned poor in vivo expansion and persistence of the transferred lymphocytes. For example, Wright et al. investigated whether mucin 1 variable number tandem repeat (VNTR)-stimulated mononuclear cells (M1SMC) can be given safely intraperitoneally to subjects with recurrent $O C$ after resection and chemotherapy [121]. In the study, 7 participants underwent up to 4 cycles of treatment. Each time patients were 
subjected to leukapheresis (separation of white blood cells from a blood sample) before intraperitoneal infusion of tumour-specific cytotoxic T-lymphocytes. There was no other intervention performed on the subjects. The therapy was well tolerated; the only clinical side effect was abdominal pain in one patient. Median survival was 11.5 months; one subject was free of disease at the end of the study. After the first month of immunotherapy, the tumour marker CA-125 was not significantly reduced from the statistical point of view. Nevertheless, after that time, its significance increased. The killer cells, cytokine production and memory T-lymphocytes increased after the first cycle of stimulation but plateaued or decreased after that. The percent of NK cells inversely correlated with other immune parameters [121]. Unlike other tumours which do not typically possess physical barriers that would prevent their interactions with CAR T cells, many OC tumours have formidable barriers that render these masses inaccessible to invasion by immune cells.

The next clinical trial involved 15 patients, and the treatment was based on lentiviraltransduced chimeric antigen receptor (CAR)-modified autologous $\mathrm{T}$ cells redirected against mesothelin (CART-meso) cells (single infusion 1-3 $\times 10^{7}-10^{8}$ cells $/ \mathrm{m}^{2}$ i.v.). The most common adverse events were low-grade fatigue and nausea observed in $47 \%$ and $40 \%$ of the group. Lymphodepletion improved the initial expansion of CART-meso cells but did not impact CART-meso cell persistence. However, researchers detected CAR DNA in tumour biopsies and ascites from several patients, suggesting CART-meso have infiltrating abilities. A single infusion of CART-meso cells was safe in this human study but produced minimal anti-tumour activity. The best overall response was stable disease (11/15 patients) [122]. Studies evaluating a fully human anti-mesothelin and other CARs in OC treatment are ongoing (Table 3).

Table 3. Actually running studies including the application of CAR-T chimeric antigen receptors in solid cancer treatment, according to ClinicalTrials.gov.

\begin{tabular}{|c|c|c|c|c|}
\hline Study Title & Summary & Intervention & Phase & Locations \\
\hline $\begin{array}{l}\text { The Fourth Generation } \\
\text { CART-cell Therapy for } \\
\text { Refractory-Relapsed OC }\end{array}$ & $\begin{array}{l}\text { The goal of this clinical } \\
\text { trial is to study the safety } \\
\text { and feasibility of } \\
\text { anti-Mesothelin Chimeric } \\
\text { Antigen Receptor T-Cell } \\
\text { (MESO CAR-T cells) } \\
\text { therapy for } \\
\text { Refractory-Relapsed OC }\end{array}$ & $\begin{array}{l}\text { Autologous genetically } \\
\text { modified anti-MESO CAR } \\
\text { transduced T cells }\end{array}$ & Early 1 & $\begin{array}{c}\text { Shanghai 6th People's } \\
\text { Hospital } \\
\text { Shanghai, China }\end{array}$ \\
\hline $\begin{array}{c}\text { Safety and Effectiveness } \\
\text { of MESO-CAR T-Cells } \\
\text { Therapy for Relapsed } \\
\text { and Refractory Epithelial } \\
\text { Ovarian Cancer }\end{array}$ & $\begin{array}{l}\text { The goal of this clinical trial } \\
\text { is to study the feasibility } \\
\text { and efficacy of anti-MESO } \\
\text { antigen receptors (CARs) } \\
\text { T-cell therapy for relapsed } \\
\text { and refractory epithelial } \\
\text { ovarian cancer }\end{array}$ & $\begin{array}{c}\text { Retroviral } \\
\text { vector-transduced } \\
\text { autologous T cells to } \\
\text { express anti-MESO CARs } \\
\text { Fludarabine } 30 \mathrm{mg} / \mathrm{m}^{2} / \mathrm{d} \\
\text { Cyclophosphamide } 300 \\
\mathrm{mg} / \mathrm{m}^{2} / \mathrm{d}\end{array}$ & 1 and 2 & $\begin{array}{l}\text { The Second Affiliated } \\
\text { hospital of Zhejiang } \\
\text { University School of } \\
\text { Medicine Hangzhou, } \\
\text { China }\end{array}$ \\
\hline $\begin{array}{c}\text { A Clinical Trial of } \\
\text { MESO-CAR T-Cells } \\
\text { Therapy for Relapsed } \\
\text { and Refractory Ovarian } \\
\text { Cancer MESO-CAR T } \\
\text { Cells }\end{array}$ & $\begin{array}{l}\text { The goal of this clinical } \\
\text { trial is to study the } \\
\text { feasibility and efficacy of } \\
\text { anti-MESO antigen } \\
\text { receptors (CARs) T-cell } \\
\text { therapy for relapsed and } \\
\text { refractory ovarian cancer }\end{array}$ & $\begin{array}{c}\text { Retroviral } \\
\text { vector-transduced } \\
\text { autologous T cells to } \\
\text { express anti-MESO CARs } \\
\text { Fludarabine } 30 \mathrm{mg} / \mathrm{m}^{2} / \mathrm{d} ; \\
\text { Cyclophosphamide } 300 \\
\mathrm{mg} / \mathrm{m}^{2} / \mathrm{d}\end{array}$ & Early 1 & $\begin{array}{l}\text { The Second Affiliated } \\
\text { hospital of Zhejiang } \\
\text { University School of } \\
\text { Medicine Hangzhou, } \\
\text { China }\end{array}$ \\
\hline
\end{tabular}


Table 3. Cont.

\begin{tabular}{|c|c|c|c|c|}
\hline Study Title & Summary & Intervention & Phase & Locations \\
\hline $\begin{array}{l}\text { A Single-Center, Phase I } \\
\text { Clinical Study to } \\
\text { Evaluate the Safety, } \\
\text { Tolerability and Efficacy } \\
\text { of LCAR-M23, a } \\
\text { CAR-T-Cell Therapy } \\
\text { Targeting MSLN in } \\
\text { Patients With Relapsed } \\
\text { and Refractory Epithelial } \\
\text { Ovarian Cancer }\end{array}$ & $\begin{array}{c}\text { This study is a prospective, } \\
\text { single-arm, single-centre, } \\
\text { open-label, single-dose } \\
\text { dose finding and extension } \\
\text { study to evaluate the safety, } \\
\text { tolerability, } \\
\text { pharmacokinetics and } \\
\text { anti-tumour efficacy } \\
\text { profiles of the LCAR-M23 } \\
\text { CAR-T-cell therapy in } \\
\text { subjects with relapsed and } \\
\text { refractory epithelial } \\
\text { ovarian cancer after prior } \\
\text { adequate standard of care }\end{array}$ & $\begin{array}{c}\text { LCAR-M23 cells } \\
\text { Prior to infusion of } \\
\text { LCAR-M23, subjects will } \\
\text { receive a premedication } \\
\text { regimen } \\
\text { (IV of cyclophosphamide } \\
300 \mathrm{mg} / \mathrm{m}^{2} \text { and } \\
\text { fludarabine } 30 \mathrm{mg} / \mathrm{m}^{2} \\
\text { once daily for } 3 \text { days) }\end{array}$ & 1 & $\begin{array}{c}\text { Shanghai East Hospital } \\
\text { Shanghai, China }\end{array}$ \\
\hline $\begin{array}{c}\text { A Single-Arm, } \\
\text { Single-Center, } \\
\text { Open-Label Pilot Study } \\
\text { of Anti-ALPP CART-cells } \\
\text { in Patient With Alkaline } \\
\text { Phosphatase, Placental } \\
\text { (ALPP)-Positive } \\
\text { Metastatic Ovarian and } \\
\text { Endometrial Cancer }\end{array}$ & $\begin{array}{l}\text { The goal of this clinical trial } \\
\text { is to evaluate the safety } \\
\text { and efficacy of anti-ALPP } \\
\text { chimeric antigen receptor } \\
\text { (CAR)-modified T (CAR-T) } \\
\text { cells in treating patients } \\
\text { with ALPP-positive } \\
\text { metastatic ovarian and } \\
\text { endometrial cancer. }\end{array}$ & $\begin{array}{c}\text { CART treatment } \\
\text { Retroviral } \\
\text { vector-transduced } \\
\text { autologous T cells to } \\
\text { express anti-ALPP CARs } \\
\text { Cyclophosphamide will be } \\
\text { administered at dose of } \\
20 \mathrm{mg} / \mathrm{kg} \text { for } 1 \text { day and } \\
\text { then fludarabine will be } \\
\text { given for the next } 3 \text { days } \\
\text { with } 35 \mathrm{mg} / \mathrm{m}^{2} \text { and then } \\
\text { the CAR-T cells will be } \\
\text { administered }\end{array}$ & $\begin{array}{c}1 \text { and } \\
2\end{array}$ & $\begin{array}{l}\text { Xinqiao Hospital of } \\
\text { Chongqing' China }\end{array}$ \\
\hline $\begin{array}{l}\text { An Exploratory Study of } \\
\alpha \text { PD1-MSLN-CAR T } \\
\text { Cells Secreting PD-1 } \\
\text { Nanobodies for the } \\
\text { Treatment of } \\
\text { MSLN-positive } \\
\text { Advanced Solid Tumours }\end{array}$ & $\begin{array}{l}\text { This is a single arm, } \\
\text { open-label, dose escalation } \\
\text { clinical study to evaluate } \\
\text { the safety and tolerability } \\
\text { of autologous mesothelin } \\
\text { (MSLN)-targeted chimeric } \\
\text { antigen receptor } \\
\text { (MSLN-CAR) T cells } \\
\text { secreting PD-1 nanobodies } \\
\text { ( } \alpha \text { PD1-MSLN-CAR T cells) } \\
\text { in patients with solid } \\
\text { tumours }\end{array}$ & $\begin{array}{c}\alpha \text { PD1-MSLN-CAR T cells } \\
\text { Subjects will undergo } \\
\text { leukapheresis to isolate } \\
\text { peripheral blood } \\
\text { mononuclear cells (PBMCs) } \\
\text { for the production of } \\
\alpha \text { PD1-MSLN-CAR T cells. } \\
\text { The initial dose of } 1 \times 10^{5} \\
\text { CAR+ T cells } / \text { kg will be } \\
\text { infused on day } 0 \text {. }\end{array}$ & Early 1 & $\begin{array}{l}\text { Shanghai Tenth } \\
\text { people's Hospital } \\
\text { Shanghai, } \\
\text { China }\end{array}$ \\
\hline $\begin{array}{l}\text { Phase I Study Evaluating } \\
\text { Benefit of PRGN-3005 } \\
\text { UltraCAR-T'M } \\
\text { (Autologous CAR T } \\
\text { Cells) in Advanced Stage } \\
\text { Platinum Resistant } \\
\text { Ovarian Cancer Patients }\end{array}$ & $\begin{array}{l}\text { This is a study to identify } \\
\text { the best dose and side } \\
\text { effects of modified immune } \\
\text { cells PRGN-3005 } \\
\text { (autologous chimeric } \\
\text { antigen receptor (CAR) T } \\
\text { cells developed by } \\
\text { Precigen, Inc) in treating } \\
\text { patients with ovarian, } \\
\text { fallopian tube, or primary } \\
\text { peritoneal cancer that has } \\
\text { spread to other places in } \\
\text { the body, that has come } \\
\text { back and is resistant to } \\
\text { platinum chemotherapy. }\end{array}$ & $\begin{array}{l}\text { PRGN-3005 UltraCAR-T } \\
\text { cells } \\
\text { given IP or IV }\end{array}$ & 1 & $\begin{array}{c}\text { Fred Hutch/University } \\
\text { of Washington Cancer } \\
\text { Consortium } \\
\text { Seattle, } \\
\text { United States }\end{array}$ \\
\hline
\end{tabular}


Table 3. Cont.

\begin{tabular}{|c|c|c|c|c|}
\hline Study Title & Summary & Intervention & Phase & Locations \\
\hline $\begin{array}{c}\text { A Phase } 1 \text { Study of } \\
\text { Autologous Activated } \\
\text { T-cells Targeting the } \\
\text { B7-H3 Antigen in } \\
\text { Subjects With Recurrent } \\
\text { Epithelial Ovarian } \\
\text { Cancer }\end{array}$ & $\begin{array}{l}\text { This is single centre, } \\
\text { open-label phase } 1 \text { dose } \\
\text { escalation trial that uses } \\
\text { modified } 3+3 \text { design to } \\
\text { identify a recommended } \\
\text { phase } 2 \text { dose (RP2D) of } \\
\text { CAR.B7-H3 T cell. } \\
\text { An expansion cohort will } \\
\text { enrol additional subjects at } \\
\text { the RP2D for a total } \\
\text { enrolment of up to } 21 \\
\text { subjects on the protocol. }\end{array}$ & $\begin{array}{c}\text { CAR.B7-H3 } \\
\text { Two dose levels will be } \\
\text { evaluated: Dose Level } 1 \\
\left(7.5 \times 10^{7} \text { cells } / \text { infusion }\right) \\
\text { dose Level } 2\left(2 \times 10^{8}\right. \\
\text { cells /infusion }) .\end{array}$ & 1 & $\begin{array}{c}\text { Lineberger } \\
\text { Comprehensive Cancer } \\
\text { Center } \\
\text { Chapel Hill, } \\
\text { United States }\end{array}$ \\
\hline $\begin{array}{l}\text { Phase I Clinical Trial of } \\
\text { Adoptive Transfer of } \\
\text { Autologous Folate } \\
\text { Receptor-Alpha } \\
\text { Redirected T Cells for } \\
\text { Recurrent High Grade } \\
\text { Serous Ovarian, } \\
\text { Fallopian Tube, or } \\
\text { Primary Peritoneal } \\
\text { Cancer }\end{array}$ & $\begin{array}{l}\text { Phase I study to establish } \\
\text { safety and feasibility of } \\
\text { IP(L) administered } \\
\text { lentiviral transduced } \\
\text { MOv19-BBz CAR T cells } \\
\text { with or without } \\
\text { cyclophosphamide + } \\
\text { fludarabine as } \\
\text { lymphodepleting } \\
\text { chemotherapy. }\end{array}$ & $\begin{array}{l}\text { MOv19-BBz CAR T cells } \\
\text { IP administered lentiviral } \\
\text { transduced MOv19-BBz } \\
\text { CAR T cells with or } \\
\text { without cyclophosphamide } \\
\text { + fludarabine as } \\
\text { lymphodepleting } \\
\text { chemotherapy }\end{array}$ & 1 & $\begin{array}{c}\text { University of } \\
\text { Pennsylvania Health } \\
\text { System } \\
\text { Philadelphia, } \\
\text { United States }\end{array}$ \\
\hline $\begin{array}{l}\text { Innovative Treatment of } \\
\text { Ovarian Cancer Based on } \\
\text { Immunogene-modified T } \\
\text { Cells (IgT) }\end{array}$ & $\begin{array}{l}\text { The primary objectives are } \\
\text { to evaluate the safety and } \\
\text { efficacy of infusion of } \\
\text { autologous OC } \\
\text { immunogene-modified T } \\
\text { cells } \\
\text { (OC-IgT cells) }\end{array}$ & $\begin{array}{c}\text { OC-IgT cells. } \\
\text { Autologous human OC-IgT } \\
\text { cells }\end{array}$ & $\begin{array}{c}1 \text { and } \\
2\end{array}$ & $\begin{array}{c}\text { Shenzhen } \\
\text { Geno-immune Medical } \\
\text { Institute Shenzhen, } \\
\text { China }\end{array}$ \\
\hline
\end{tabular}

Phase 1 study of the safety,

A Phase 1 Open-Label,

Multi-Center First in

Human Study of

TnMUC1-Targeted

Genetically-Modified

Chimeric Antigen

Receptor T Cells in

Patients With Advanced

TnMUC1-Positive Solid

Tumours and Multiple Myeloma

tolerability, feasibility and

preliminary efficacy of the administration of genetically modified autologous T cells (CART-TnMUC1 cells) engineered to express a chimeric antigen receptor (CAR) capable of recognizing the tumour antigen, TnMUC1 and activating the T cell (CARTTnMUC1 cells)

Autologous Immunotherapy With Multi-target Gene-modified CAR-T/TCR-T Cell for Malignancies
This is a single arm, open-label, uni-center, phase I-II study to evaluate the safety and effectiveness of CAR-T/TCR-T-cell immunotherapy in treating with different malignancies patients (OC and 13 more)

\section{CART-TnMUC1}

Single IV administration of genetically modified autologous T cells engineered to express a TnMUC1-Targeted Genetically-Modified Chimeric Antigen (CAR) Drug: Cyclophosphamide
The Angeles Clinic and Research Institute Los Angeles and 7 others, United States

\section{CAR-T-cell} immunotherapy

According to tumour burden and other conditions, patients will be treated with

cyclophosphamide or fludarabine, then, CAR-T. cells will be infused $48-72 \mathrm{~h}$ 
Table 3. Cont.

\begin{tabular}{|c|c|c|c|c|}
\hline Study Title & Summary & Intervention & Phase & Locations \\
\hline $\begin{array}{l}\text { Phase I Study of Human } \\
\text { Chimeric Antigen } \\
\text { Receptor Modified T } \\
\text { Cells in Patients With } \\
\text { Mesothelin Expressing } \\
\text { Cancers }\end{array}$ & $\begin{array}{l}\text { Phase I study to establish } \\
\text { safety and feasibility of IV } \\
\text { or IP(L) administered } \\
\text { lentiviral transduced } \\
\text { huCART-meso cells with or } \\
\text { without lymphodepletion } \\
\text { by way of administering } \\
\text { cyclophosphamide }\end{array}$ & $\begin{array}{c}\text { huCART-meso cells } \\
\text { IV or IP(L) lentiviral } \\
\text { transduced huCART-meso } \\
\text { cells in } 6 \text { cohorts with and } \\
\text { without cyclophosphamide } \\
\text { in a } 3+3 \text { dose escalation } \\
\text { design. }\end{array}$ & 1 & $\begin{array}{l}\text { University of } \\
\text { Pennsylvania } \\
\text { Philadelphia, } \\
\text { United States }\end{array}$ \\
\hline $\begin{array}{l}\text { A Phase I Trial to Assess } \\
\text { Safety, Tolerability and } \\
\text { Anti-tumour Activity of } \\
\text { Autologous T Cell } \\
\text { Modified Chimeric } \\
\text { Antigen Receptor (CAR) } \\
\text { (CCT303-406) in Patients } \\
\text { With Relapsed or } \\
\text { Refractory HER2 Positive } \\
\text { Solid Tumours }\end{array}$ & $\begin{array}{l}\text { This clinical study is to } \\
\text { investigate the safety and } \\
\text { tolerability of CCT303-406 } \\
\text { CAR modified autologous } \\
\text { T cells (CCT303-406) in } \\
\text { subjects with relapsed or } \\
\text { refractory stage IV } \\
\text { metastatic HER2-positive } \\
\text { solid tumours }\end{array}$ & $\begin{array}{c}\text { CCT303-406 } \\
\text { Blood will be collected } \\
\text { from subjects to isolate } \\
\text { peripheral blood } \\
\text { mononuclear cells for the } \\
\text { production of CCT303-406. } \\
\text { cyclophosphamide and } \\
\text { fludarabine for } \\
\text { lymphodepletion followed } \\
\text { by a single dose of } \\
\text { CCT303-406 via IV. }\end{array}$ & 1 & $\begin{array}{c}\text { Zhongshan Hospital } \\
\text { Affiliated to Fudan } \\
\text { University } \\
\text { Shanghai, China }\end{array}$ \\
\hline
\end{tabular}

BW-body weight, IP—intraperitoneal, IP(L)—intrapleural, IV—intravenous, TC—-tumour cells.

Challenges such as the immunosuppressive character of the TME, CAR-T cell persistence and trafficking to the tumour seem to limit CAR-T-cell efficacy in solid cancers [123]. Over the past decade, significant efforts have been made to develop CARs targeting OC. Comprehensive descriptions of promising CAR candidates have recently been published $[33,79-81,97,124]$. Because of the immunosuppressive cells in the TME, including tumour-associated macrophages (TAMs), myeloid-derived suppressor cells (MDSCs) and regulatory $\mathrm{T}$ cells (Tregs), the anti-tumour immune function of OC patients is significantly attenuated. Thus, patients have the poorest outcomes after receiving immunotherapy. Numerous CAR strategies to affect the TME have been proposed, these were either directly aiming at cell surface components supporting the tumour, or combining the tumourtargeted CAR with anti-immuno-inhibitory drugs such as checkpoint inhibitors [124].

Cancer stem cells as a new target for CARsAs results of various studies suggest a notable phenomenon in the typical clinical course of $\mathrm{OC}$ is stem cell-driven repopulation. From the perspective of our research and the role of cancer stem cells (CSCs) in developing and advancing solid tumour malignancies, we can suggest that this disease is particularly well-suited for this purpose. Three theories describe the origin of CSCs: a normal stem cell, transit-amplifying cell, or a normal progenitor cell [125]. CSCs are precursors and protoplasts of heterogeneous mature cancer cells with a huge capacity for self-renewal and are believed to be a key factor for tumour development and recurrence. It is well-known that CSC cells are resistant to chemotherapy and radiotherapy. In view of this fact, it seems worthwhile to focus on immunotherapy. According to many confirmed clinical data, it has been advocated as a promising strategy to control problematic CSC cells $[30,126]$.

CSC cells, similarly to tissue stem cells (TSC), have an enhanced ability to resist harmful internal and external factors. Due to an excellent ability to repair DNA damage, resistance to low proliferation rates, upregulation of detoxification enzymes and efflux pumps, CSC cells are much less sensitive to the use of radiotherapy, cytotoxic drugs or targeted therapies. Because CSCs seek to mimic the function of their healthy counterparts, in preliminary studies researchers used the same techniques, such as ALDH1s's detoxifying enzymatic activity, that were used to define stem cells in putative tissues of origin, particularly the fallopian tube and ovaries. In contrast, other studies have focused on surface proteins. These proteins' expression has previously been demonstrated on cells with stem 
cell properties in other types of cancer, such as CD24, CD44 and CD133, to identify CSCs in OC [127].

Ovarian cancer stem cells (OCSC)s were identified only a few years ago. Parte et al. have investigated 34 samples of OC human tissue and revealed the presence and different distribution of various CSC surface markers (CD133, CD24 and CD44), functional CSC markers (ALDH1/2) and cell proliferation (KI67) specific markers [127]. Klapdor et al. developed a novel anti-CD24 CAR targeting OC. This new 3rd generation anti-CD24 CAR has been shown to be highly specific and exhibits powerful cytotoxic activity against CD24-positive OC cell lines and primary cells [78]. Also, specific elimination of ovarian CSCs by anti-CD133-CAR expressing NK92 cells offers quite an optimistic strategy that, if confirmed in vivo, should form the foundation of future clinical research aimed at preventing relapses [128].

Collected data suggest that many surface markers present on CSCs surface (CD133, CD44, CD47) could be used as a target for chimeric antigen receptors. Note, that markers must be selected with exceptional due care and be tumour-specific, not expressed via healthy cells, as it could result in severe side effects. Embellishing or arming CARs to be switchable (toxicity controlled by antigen dosage) could be a method of choice. Irrespective of this, OCSCs exhibit significant phenotypic and functional heterogeneity, which is vital in designing and developing targeted therapies. For this reason, it is necessary to conduct research studies on a regular basis to explain all the heterogeneity features of CSCs in OC. The same applies to the challenge of determining their association with histopathological subtypes, clinical parameters and molecular aberrations. Given the recent advances in the analysis of single cells at the genetic level, transcriptome and proteome profiling, it seems we have finally amassed enough tools and knowledge to address this issue.

Author Contributions: Conceptualisation, K.M.T. and B.D.; investigation, K.M.T. and B.D.; writingoriginal draft preparation, K.M.T.; writing-review and editing, B.D. and S.J.T.; supervision, S.J.T. All authors have read and agreed to the published version of the manuscript.

Funding: This research was financed through a statutory subsidy awarded to the Faculty of Health Sciences of the Medical University of Bialystok, Poland.

Institutional Review Board Statement: Not applicable.

Informed Consent Statement: Not applicable.

Data Availability Statement: Not applicable.

Acknowledgments: Not applicable.

Conflicts of Interest: The authors declare no conflict of interest. The funders have not participated in the design of the study; in the collection, analyses, or interpretation of data; in the writing of the manuscript, or in the decision to publish the results.

$\begin{array}{ll}\text { Abbreviations } & \\ \text { ADCC } & \text { antibody-dependent cytotoxicity } \\ \text { ANXA2 } & \text { annexin 2 } \\ \text { APCs } & \text { antigen-presenting cells } \\ \text { CAR } & \text { chimeric antigen receptors } \\ \text { CCC } & \text { clear cell carcinomas } \\ \text { CCC } & \text { clear cell carcinoma } \\ \text { CSC } & \text { cancer stem cell } \\ \text { CTLA-4 } & \text { cytotoxic T lymphocyte-associated antigen-4 } \\ \text { CXCR1 } & \text { interleukin-8 receptor alpha } \\ \text { dCas9 } & \text { catalytically inactive Cas9 } \\ \text { EC } & \text { endometrioid carcinomas } \\ \text { ECM } & \text { extracellular matrix } \\ \text { EGFR } & \text { epidermal growth factor receptor }\end{array}$




\begin{tabular}{|c|c|}
\hline $\mathrm{Fab}$ & antigen-binding fragment \\
\hline FBP & folate binding protein \\
\hline FIGO & International Federation of Gynaecology and Obstetrics \\
\hline FR- $\alpha$ & folate receptor- $\alpha$ \\
\hline FSHR & follicle-stimulating hormone receptor \\
\hline GM-CSF & granulocyte-macrophage colony-stimulating factor \\
\hline GPI & glycosylphosphatidylinositol \\
\hline HE4 & human epididymis protein 4 \\
\hline HER2/neu & receptor tyrosine-protein kinase erbB-2 \\
\hline HGSC & high-grade serous carcinoma \\
\hline HPV & Human Papillomavirus \\
\hline HSV-TK & herpes simplex virus I-derived thymidine kinase \\
\hline iCasp9 & caspase 9 \\
\hline IDO & indoleamine 2,3-dioxygenase \\
\hline L1-CAM & L1 cell adhesion molecule \\
\hline LGSC & low-grade serous carcinoma \\
\hline M1SMC & stimulated mononuclear cells \\
\hline $\mathrm{mAb}$ & antigen-specific monoclonal antibody \\
\hline $\mathrm{MC}$ & mucinous carcinoma \\
\hline MDSCs & myeloid-derived suppressor cells \\
\hline MHC & major histocompatibility complex \\
\hline MMPs & matrix metalloproteinases \\
\hline MSLN & mesothelin \\
\hline MUC16 & mucin 16 \\
\hline NK & natural killer \\
\hline $\mathrm{OC}$ & ovarian cancer \\
\hline OCSCs & ovarian cancer stem cells \\
\hline OSE & ovarian surface epithelium \\
\hline PARP1 & poly [ADP-ribose] polymerase 1 \\
\hline PCR & polymerase chain reaction \\
\hline PD-1 & Programmed cell death-1 \\
\hline PD-L1/L2 & programmed death-ligand $1 / 2$ \\
\hline SB & sleeping beauty transposon system \\
\hline $\mathrm{scFv}$ & single-chain variable fragment \\
\hline TAMs & tumour-associated macrophages \\
\hline TGF $\beta$ & transforming growth factor beta \\
\hline TIR & terminal inverted repeats \\
\hline TME & tumour microenvironment \\
\hline TNF & tumour necrosis factor \\
\hline Tregs & regulatory $\mathrm{T}$ cells \\
\hline uPAR & urokinase plasminogen activator receptor \\
\hline VEGF-A & vascular endothelial growth factor A \\
\hline VNTR & mucin 1 variable number tandem repeat \\
\hline Z-VAD & $\begin{array}{l}\text { pan-caspase inhibitor carbobenzoxy-valyl-alanyl-aspartyl-[O- } \\
\text { methyl]-fluoromethylketone }\end{array}$ \\
\hline
\end{tabular}

\section{References}

1. Siegel, R.L.; Miller, K.D.; Jemal, A. Cancer Statistics, 2019. CA Cancer J. Clin. 2019, 69, 7-34. [CrossRef]

2. Bray, F.; Ferlay, J.; Soerjomataram, I.; Siegel, R.L.; Torre, L.A.; Jemal, A. Global Cancer Statistics 2018: GLOBOCAN Estimates of Incidence and Mortality Worldwide for 36 Cancers in 185 Countries. CA Cancer J. Clin. 2018, 68, 394-424. [CrossRef]

3. Torre, L.A.; Trabert, B.; DeSantis, C.E.; Miller, K.D.; Samimi, G.; Runowicz, C.D.; Gaudet, M.M.; Jemal, A.; Siegel, R.L. Ovarian Cancer Statistics, 2018. CA Cancer J. Clin. 2018, 68, 284-296. [CrossRef]

4. Jelovac, D.; Armstrong, D.K. Recent Progress in the Diagnosis and Treatment of Ovarian Cancer. CA Cancer J. Clin. 2011, 61, 183-203. [CrossRef] [PubMed] 
5. Menon, U.; Karpinskyj, C.; Gentry-Maharaj, A. Ovarian Cancer Prevention and Screening. Obstet. Gynecol. 2018, 131, 909-927. [CrossRef] [PubMed]

6. Stewart, C.; Ralyea, C.; Lockwood, S. Ovarian Cancer: An Integrated Review. Semin. Oncol. Nurs. 2019, 35, 151-156. [CrossRef] [PubMed]

7. Elias, K.M.; Guo, J.; Bast, R.C., Jr. Early Detection of Ovarian Cancer. Hematol. Oncol. Clin. N. Am. 2018, 32, 903-914. [CrossRef] [PubMed]

8. Reid, B.M.; Permuth, J.B.; Sellers, T.A. Epidemiology of Ovarian Cancer: A Review. Cancer Biol. Med. 2017, 14, 9-32. [CrossRef] [PubMed]

9. Webb, P.M.; Jordan, S.J. Epidemiology of Epithelial Ovarian Cancer. Best Pract. Res. Clin. Obstet. Gynaecol. 2017, 41, 3-14. [CrossRef]

10. Lheureux, S.; Braunstein, M.; Oza, A.M. Epithelial Ovarian Cancer: Evolution of Management in the Era of Precision Medicine. CA Cancer J. Clin. 2019, 69, 280-304. [CrossRef]

11. Lengyel, E. Ovarian Cancer Development and Metastasis. Am. J. Pathol. 2010, 177, 1053-1064. [CrossRef]

12. Weidle, U.H.; Birzele, F.; Kollmorgen, G.; Rueger, R. Mechanisms and Targets Involved in Dissemination of Ovarian Cancer. Cancer Genom. Proteom. 2016, 13, 407-423. [CrossRef]

13. Kaku, T.; Ogawa, S.; Kawano, Y.; Ohishi, Y.; Kobayashi, H.; Hirakawa, T.; Nakano, H. Histological Classification of Ovarian Cancer. Med. Electron Microsc. 2003, 36, 9-17. [CrossRef] [PubMed]

14. Ramalingam, P. Morphologic, Immunophenotypic, and Molecular Features of Epithelial Ovarian Cancer. Oncology 2016, 30, 166-176.

15. Murali, R.; Davidson, B.; Fadare, O.; Carlson, J.A.; Crum, C.P.; Gilks, C.B.; Irving, J.A.; Malpica, A.; Matias-Guiu, X.; McCluggage, W.G.; et al. High-grade Endometrial Carcinomas: Morphologic and Immunohistochemical Features, Diagnostic Challenges and Recommendations. Int. J. Gynecol. Pathol. 2019, 38 (Suppl. 1), S40-S63. [CrossRef] [PubMed]

16. Prat, J. Ovarian Carcinomas: Five Distinct Diseases with Different Origins, Genetic Alterations, and Clinicopathological Features. Virchows Arch. 2012, 460, 237-249. [CrossRef]

17. Prat, J.; D'Angelo, E.; Espinosa, I. Ovarian Carcinomas: At Least Five Different Diseases with Distinct Histological Features and Molecular Genetics. Hum. Pathol. 2018, 80, 11-27. [CrossRef] [PubMed]

18. Macpherson, A.M.; Barry, S.C.; Ricciardelli, C.; Oehler, M.K. Epithelial Ovarian Cancer and the Immune System: Biology, Interactions, Challenges and Potential Advances for Immunotherapy. J. Clin. Med. 2020, 9, 2967. [CrossRef]

19. Da Silva, A.C.; Jammal, M.P.; Crispim, P.C.A.; Murta, E.F.C.; Nomelini, R.S. The Role of Stroma in Ovarian Cancer. Immunol Invest. 2020, 49, 406-424. [CrossRef]

20. Chen, G.M.; Kannan, L.; Geistlinger, L.; Kofia, V.; Safikhani, Z.; Gendoo, D.M.A.; Parmigiani, G.; Birrer, M.; Haibe-Kains, B.; Waldron, L. Consensus on Molecular Subtypes of High-Grade Serous Ovarian Carcinoma. Clin. Cancer Res. 2018, 24, 5037-5047. [CrossRef] [PubMed]

21. Ribatti, D. The Concept of Immune Surveillance against Tumors. The First Theories. Oncotarget 2017, 8, 7175-7180. [CrossRef]

22. Kochenderfer, J.N.; Rosenberg, S.A. Treating B-cell Cancer with T Cells Expressing Anti-CD19 Chimeric Antigen Receptors. Nat. Rev. Clin. Oncol. 2013, 10, 267-276. [CrossRef]

23. Yang, C.; Xia, B.R.; Zhang, Z.C.; Zhang, Y.J.; Lou, G.; Jin, W.L. Immunotherapy for Ovarian Cancer: Adjuvant, Combination, and Neoadjuvant. Front. Immunol. 2020, 11, 577869. [CrossRef] [PubMed]

24. Scarlett, U.K.; Conejo-Garcia, J.R. Modulating the Tumor Immune Microenvironment as an Ovarian Cancer Treatment Strategy. Expert Rev. Obstet. Gynecol. 2012, 7, 413-419. [CrossRef] [PubMed]

25. Sahai, E.; Astsaturov, I.; Cukierman, E.; DeNardo, D.G.; Egeblad, M.; Evans, R.M.; Fearon, D.; Greten, F.R.; Hingorani, S.R.; Hunter, T.; et al. A Framework for Advancing Our Understanding of Cancer-associated Fibroblasts. Nat. Rev. Cancer 2020, 20, 174-186. [CrossRef]

26. Hagemann, T.; Wilson, J.; Burke, F.; Kulbe, H.; Li, N.F.; Plüddemann, A.; Charles, K.; Gordon, S.; Balkwill, F.R. Ovarian Cancer Cells Polarize Macrophages Toward a Tumor-associated Phenotype. J. Immunol. 2006, 176, 5023-5032. [CrossRef]

27. Chen, F.; Hou, M.; Ye, F.; Lv, W.; Xie, X. Ovarian Cancer Cells Induce Peripheral Mature Dendritic Cells to Differentiate into Macrophagelike Cells in vitro. Int. J. Gynecol. Cancer 2009, 19, 1487-1493. [CrossRef]

28. Milne, K.; Köbel, M.; Kalloger, S.E.; Barnes, R.O.; Gao, D.; Gilks, C.B.; Watson, P.H.; Nelson, B.H. Systematic Analysis of Immune Infiltrates in High-grade Serous Ovarian Cancer Reveals CD20, FoxP3 and TIA-1 as Positive Prognostic Factors. PLoS ONE 2009, 4, e6412. [CrossRef] [PubMed]

29. Uyttenhove, C.; Pilotte, L.; Théate, I.; Stroobant, V.; Colau, D.; Parmentier, N.; Boon, T.; Van den Eynde, B.J. Evidence for a Tumoral Immune Resistance Mechanism Based on Tryptophan Degradation by Indoleamine 2,3-dioxygenase. Nat. Med. 2003, 9 , 1269-1274. [CrossRef]

30. Terraneo, N.; Jacob, F.; Dubrovska, A.; Grünberg, J. Novel Therapeutic Strategies for Ovarian Cancer Stem Cells. Front Oncol. 2020, 10, 319. [CrossRef]

31. Tewari, K.S.; Burger, R.A.; Enserro, D.; Norquist, B.M.; Swisher, E.M.; Brady, M.F.; Bookman, M.A.; Fleming, G.F.; Huang, H.; Homesley, H.D.; et al. Final Overall Survival of a Randomized Trial of Bevacizumab for Primary Treatment of Ovarian Cancer. $J$. Clin. Oncol. 2019, 37, 2317-2328. [CrossRef] [PubMed] 
32. Hombach, A.; Hombach, A.A.; Abken, H. Adoptive Immunotherapy with Genetically Engineered T Cells: Modification of the IgG1 Fc 'Spacer' Domain in the Extracellular Moiety of Chimeric Antigen Receptors Avoids 'Off-target' Activation and Unintended Initiation of an Innate Immune Response. Gene Ther. 2010, 17, 1206-1213. [CrossRef]

33. Sadelain, M.; Brentjens, R.; Rivière, I. The Basic Principles of Chimeric Antigen Receptor Design. Cancer Discov. 2013, 3, 388-398. [CrossRef] [PubMed]

34. Wu, Y.; Jiang, S.; Ying, T. From Therapeutic Antibodies to Chimeric Antigen Receptors (CARs): Making Better CARs Based on Antigen-binding Domain. Expert Opin. Biol. Ther. 2016, 16, 1469-1478. [CrossRef] [PubMed]

35. Hudecek, M.; Sommermeyer, D.; Kosasih, P.L.; Silva-Benedict, A.; Liu, L.; Rader, C.; Jensen, M.C.; Riddell, S.R. The Nonsignaling Extracellular Spacer Domain of Chimeric Antigen Receptors is Decisive for in vivo Antitumor Activity. Cancer Immunol. Res. 2015, 3, 125-135. [CrossRef]

36. Janda, A.; Eryilmaz, E.; Nakouzi, A.; Cowburn, D.; Casadevall, A. Variable Region Identical Immunoglobulins Differing in Isotype Express Different Paratopes. J. Biol. Chem. 2012, 287, 35409-35417. [CrossRef]

37. Imai, C.; Mihara, K.; Andreansky, M.; Nicholson, I.C.; Pui, C.H.; Geiger, T.L.; Campana, D. Chimeric Receptors with 4-1BB Signaling Capacity Provoke Potent Cytotoxicity Against Acute Lymphoblastic Leukemia. Leukemia 2004, 18, 676-684. [CrossRef]

38. Yeku, O.O.; Purdon, T.J.; Koneru, M.; Spriggs, D.; Brentjens, R.J. Armored CAR T Cells Enhance Antitumor Efficacy and Overcome the Tumor Microenvironment. Sci. Rep. 2017, 7, 10541. [CrossRef]

39. Eshhar, Z.; Waks, T.; Gross, G.; Schindler, D.G. Specific Activation and Targeting of Cytotoxic Lymphocytes through Chimeric Single Chains Consisting of Antibody-binding Domains and the Gamma or Zeta Subunits of the Immunoglobulin and T-cell Receptors. Proc. Natl. Acad. Sci. USA 1993, 90, 720-724. [CrossRef]

40. Kershaw, M.H.; Westwood, J.A.; Parker, L.L.; Wang, G.; Eshhar, Z.; Mavroukakis, S.A.; White, D.E.; Wunderlich, J.R.; Canevari, S.; Rogers-Freezer, L.; et al. A Phase I Study on Adoptive Immunotherapy Using Gene-modified T Cells for Ovarian Cancer. Clin. Cancer Res. 2006, 12, 6106-6115. [CrossRef]

41. O'Neill, R.E.; Du, W.; Mohammadpour, H.; Alqassim, E.; Qiu, J.; Chen, G.; McCarthy, P.L.; Lee, K.P.; Cao, X. T Cell-Derived CD70 Delivers an Immune Checkpoint Function in Inflammatory T Cell Responses. J. Immunol. 2017, 199, 3700-3710. [CrossRef]

42. Savoldo, B.; Ramos, C.A.; Liu, E.; Mims, M.P.; Keating, M.J.; Carrum, G.; Kamble, R.T.; Bollard, C.M.; Gee, A.P.; Mei, Z.; et al. CD28 Costimulation Improves Expansion and Persistence of Chimeric Antigen Receptor-modified T Cells in Lymphoma Patients. J. Clin. Invest. 2011, 121, 1822-1826. [CrossRef]

43. Till, B.G.; Jensen, M.C.; Wang, J.; Qian, X.; Gopal, A.K.; Maloney, D.G.; Lindgren, C.G.; Lin, Y.; Pagel, J.M.; Budde, L.E.; et al. CD20-specific Adoptive Immunotherapy for Lymphoma Using a Chimeric Antigen Receptor with Both CD28 and 4-1BB Domains: Pilot Clinical Trial Results. Blood 2012, 119, 3940-3950. [CrossRef]

44. Haso, W.; Lee, D.W.; Shah, N.N.; Stetler-Stevenson, M.; Yuan, C.M.; Pastan, I.H.; Dimitrov, D.S.; Morgan, R.A.; FitzGerald, D.J.; Barrett, D.M.; et al. Anti-CD22-chimeric Antigen Receptors Targeting B-cell Precursor Acute Lymphoblastic Leukemia. Blood 2013, 121, 1165-1174. [CrossRef]

45. Chmielewski, M.; Hombach, A.A.; Abken, H. Of CARs and TRUCKs: Chimeric Antigen Receptor (CAR) T Cells Engineered with an Inducible Cytokine to Modulate the Tumor Stroma. Immunol. Rev. 2014, 257, 83-90. [CrossRef]

46. Rajan, T.S.; Gugliandolo, A.; Bramanti, P.; Mazzon, E. In Vitro-Transcribed mRNA Chimeric Antigen Receptor T Cell (IVT mRNA CAR T) Therapy in Hematologic and Solid Tumor Management: A Preclinical Update. Int. J. Mol. Sci. 2020, 21, 6514. [CrossRef]

47. Pang, Y.; Hou, X.; Yang, C.; Liu, Y.; Jiang, G. Advances on Chimeric Antigen Receptor-modified T-cell Therapy for Oncotherapy. Mol. Cancer. 2018, 17, 91. [CrossRef] [PubMed]

48. Zhou, H.S.; Liu, D.P.; Liang, C.C. Challenges and Strategies: The Immune Responses in Gene Therapy. Med. Res. Rev. 2004, 24, 748-761. [CrossRef]

49. Aronovich, E.L.; McIvor, R.S.; Hackett, P.B. The Sleeping Beauty Transposon System: A Non-viral Vector for Gene Therapy. Hum. Mol. Genet. 2011, 20, R14-R20. [CrossRef] [PubMed]

50. Link, C.J., Jr.; Moorman, D.; Seregina, T.; Levy, J.P.; Schabold, K.J. A Phase I Trial of in vivo Gene Therapy with the Herpes Simplex Thymidine Kinase/Ganciclovir System for the Treatment of Refractory or Recurrent Ovarian Cancer. Hum. Gene Ther. 1996, 7, 1161-1179. [CrossRef] [PubMed]

51. Hu, W.S.; Pathak, V.K. Design of Retroviral Vectors and Helper Cells for Gene Therapy. Pharmacol. Rev. 2000, 52, $493-511$.

52. Li, Q.; Kay, M.A.; Finegold, M.; Stratford-Perricaudet, L.D.; Woo, S.L. Assessment of Recombinant Adenoviral Vectors for Hepatic Gene Therapy. Hum. Gene Ther. 1993, 4, 403-409. [CrossRef]

53. Isayeva, T.; Ren, C.; Ponnazhagan, S. Recombinant Adeno-associated Virus 2-mediated Antiangiogenic Prevention in a Mouse Model of Intraperitoneal Ovarian Cancer. Clin. Cancer Res. 2005, 11, 1342-1347.

54. Fraley, R.; Subramani, S.; Berg, P.; Papahadjopoulos, D. Introduction of Liposome-encapsulated SV40 DNA into Cells. J. Biol. Chem. 1980, 255, 10431-10435. [CrossRef]

55. Zhao, Y.; Zheng, Z.; Cohen, C.J.; Gattinoni, L.; Palmer, D.C.; Restifo, N.P.; Rosenberg, S.A.; Morgan, R.A. High-efficiency Transfection of Primary Human and Mouse T Lymphocytes Using RNA Electroporation. Mol. Ther. 2006, 151-159. [CrossRef] [PubMed]

56. Hartmann, J.; Schüßler-Lenz, M.; Bondanza, A.; Buchholz, C.J. Clinical Development of CAR T Cells-challenges and Opportunities in Translating Innovative Treatment Concepts. EMBO Mol. Med. 2017, 9, 1183-1197. [CrossRef] 
57. Hamm, A.; Krott, N.; Breibach, I.; Blindt, R.; Bosserhoff, A.K. Efficient Transfection Method for Primary Cells. Tissue Eng. 2002, 8, 235-245. [CrossRef]

58. Stevens, J.M.; Galyov, E.E.; Stevens, M.P. Actin-dependent Movement of Bacterial Pathogens. Nat. Rev. Microbiol. 2006, 4, 91-101. [CrossRef]

59. Monjezi, R.; Miskey, C.; Gogishvili, T.; Schleef, M.; Schmeer, M.; Einsele, H.; Ivics, Z.; Hudecek, M. Enhanced CAR T-cell Engineering Using Non-viral Sleeping Beauty Transposition from Minicircle Vectors. Leukemia 2017, 31, 186-194. [CrossRef] [PubMed]

60. Amberger, M.; Ivics, Z. Latest Advances for the Sleeping Beauty Transposon System: 23 Years of Insomnia but Prettier than Ever: Refinement and Recent Innovations of the Sleeping Beauty Transposon System Enabling Novel, Nonviral Genetic Engineering Applications. Bioessays 2020, 42, e2000136. [CrossRef] [PubMed]

61. Maude, S.L.; Laetsch, T.W.; Buechner, J.; Rives, S.; Boyer, M.; Bittencourt, H.; Bader, P.; Verneris, M.R.; Stefanski, H.E.; Myers, G.D.; et al. Tisagenlecleucel in Children and Young Adults with B-Cell Lymphoblastic Leukemia. N. Engl. J. Med. 2018, 378, 439-448. [CrossRef] [PubMed]

62. Jinek, M.; Chylinski, K.; Fonfara, I.; Hauer, M.; Doudna, J.A.; Charpentier, E. A Programmable Dual-RNA-guided DNA Endonuclease in Adaptive Bacterial Immunity. Science 2012, 337, 816-821. [CrossRef]

63. Kovač, A.; Miskey, C.; Menzel, M.; Grueso, E.; Gogol-Döring, A.; Ivics, Z. RNA-guided Retargeting of Sleeping Beauty Transposition in Human Cells. Elife 2020, 9, e53868. [CrossRef] [PubMed]

64. Belur, L.R.; Podetz-Pedersen, K.M.; Sorenson, B.S.; Hsu, A.H.; Parker, J.B.; Carlson, C.S.; Saltzman, D.A.; Ramakrishnan, S.; McIvor, R.S. Inhibition of Angiogenesis and Suppression of Colorectal Cancer Metastatic to the Liver Using the Sleeping Beauty Transposon System. Mol. Cancer 2011, 10, 14. [CrossRef]

65. Magnani, C.F.; Turazzi, N.; Benedicenti, F.; Calabria, A.; Tenderini, E.; Tettamanti, S.; Giordano Attianese, G.M.; Cooper, L.J.; Aiuti, A.; Montini, E.; et al. Immunotherapy of Acute Leukemia by Chimeric Antigen Receptor-modified Lymphocytes Using an Improved Sleeping Beauty Transposon Platform. Oncotarget 2016, 7, 51581-51597. [CrossRef]

66. Ohlfest, J.R.; Demorest, Z.L.; Motooka, Y.; Vengco, I.; Oh, S.; Chen, E.; Scappaticci, F.A.; Saplis, R.J.; Ekker, S.C.; Low, W.C.; et al. Combinatorial Antiangiogenic Gene Therapy by Nonviral Gene Transfer Using the Sleeping Beauty Transposon Causes Tumor Regression and Improves Survival in Mice Bearing Intracranial Human Glioblastoma. Mol. Ther. 2005, 12, 778-788. [CrossRef] [PubMed]

67. Xu, X.; Qiu, J.; Sun, Y. The Basics of CAR T Design and Challenges in Immunotherapy of Solid Tumors-Ovarian Cancer as a Model. Hum. Vaccin. Immunother. 2017, 13, 1548-1555. [CrossRef] [PubMed]

68. Pehlivan, K.C.; Duncan, B.B.; Lee, D.W. CAR-T Cell Therapy for Acute Lymphoblastic Leukemia: Transforming the Treatment of Relapsed and Refractory Disease. Curr. Hematol. Malig. Rep. 2018, 13, 396-406. [CrossRef] [PubMed]

69. Zhang, Q.; Hu, H.; Chen, S.Y.; Liu, C.J.; Hu, F.F.; Yu, J.; Wu, Y.; Guo, A.Y. Transcriptome and Regulatory Network Analyses of CD19-CAR-T Immunotherapy for B-ALL. Genom. Proteom. Bioinform. 2019, 17, 190-200. [CrossRef]

70. Goel, S.; Duda, D.G.; Xu, L.; Munn, L.L.; Boucher, Y.; Fukumura, D.; Jain, R.K. Normalization of the Vasculature for Treatment of Cancer and Other Diseases. Physiol. Rev. 2011, 91, 1071-1121. [CrossRef]

71. Bagley, S.J.; O’Rourke, D.M. Clinical Investigation of CAR T Cells for Solid Tumors: Lessons Learned and Future Directions. Pharmacol. Ther. 2020, 205, 107419. [CrossRef]

72. Ma, S.; Li, X.; Wang, X.; Cheng, L.; Li, Z.; Zhang, C.; Ye, Z.; Qian, Q. Current Progress in CAR-T Cell Therapy for Solid Tumors. Int. J. Biol. Sci. 2019, 15, 2548-2560. [CrossRef]

73. Abbott, R.C.; Cross, R.S.; Jenkins, M.R. Finding the Keys to the CAR: Identifying Novel Target Antigens for T Cell Redirection Immunotherapies. Int. J. Mol. Sci. 2020, 21, 515. [CrossRef]

74. Titov, A.; Valiullina, A.; Zmievskaya, E.; Zaikova, E.; Petukhov, A.; Miftakhova, R.; Bulatov, E.; Rizvanov, A. Advancing CAR T-Cell Therapy for Solid Tumors: Lessons Learned from Lymphoma Treatment. Cancers 2020, 12, 125. [CrossRef]

75. Anderson, K.G.; Stromnes, I.M.; Greenberg, P.D. Obstacles Posed by the Tumor Microenvironment to T-cell Activity: A Case for Synergistic Therapies. Cancer Cell 2017, 31, 311-325. [CrossRef]

76. Straathof, K.C.; Pulè, M.A.; Yotnda, P.; Dotti, G.; Vanin, E.F.; Brenner, M.K.; Heslop, H.E.; Spencer, D.M.; Rooney, C.M. An Inducible Caspase 9 Safety Switch for T-cell Therapy. Blood 2005, 105, 4247-4254. [CrossRef]

77. Hung, C.F.; Xu, X.; Li, L.; Ma, Y.; Jin, Q.; Viley, A.; Allen, C.; Natarajan, P.; Shivakumar, R.; Peshwa, M.V.; et al. Development of Anti-Human Mesothelin-Targeted Chimeric Antigen Receptor Messenger RNA-Transfected Peripheral Blood Lymphocytes for Ovarian Cancer Therapy. Hum. Gene Ther. 2018, 29, 614-625. [CrossRef]

78. Klapdor, R.; Wang, S.; Morgan, M.; Dörk, T.; Hacker, U.; Hillemanns, P.; Büning, H.; Schambach, A. Characterization of a Novel Third-Generation Anti-CD24-CAR against Ovarian Cancer. Int. J. Mol. Sci. 2019, 20, 660. [CrossRef] [PubMed]

79. Li, Y.; Hermanson, D.L.; Moriarity, B.S.; Kaufman, D.S. Human iPSC-Derived Natural Killer Cells Engineered with Chimeric Antigen Receptors Enhance Anti-tumor Activity. Cell Stem Cell 2018, 23, 181-192.e5. [CrossRef] [PubMed]

80. Leong, L.; Tan, H.L.; Cua, S.; Yong, K.S.M.; Chen, Q.; Choo, A. Preclinical Activity of Embryonic Annexin A2-Specific Chimeric Antigen Receptor T Cells against Ovarian Cancer. Int. J. Mol. Sci. 2020, 21, 381. [CrossRef] [PubMed]

81. Ao, X.; Yang, Y.; Li, W.; Tan, Y.; Guo, W.; Ao, L.; He, X.; Wu, X.; Xia, J.; Xu, X.; et al. Anti- $\alpha$ FR CAR-engineered NK-92 Cells Display Potent Cytotoxicity against $\alpha$ FR-positive Ovarian Cancer. J. Immunother. 2019, 42, 284-296. [CrossRef] 
82. Ng, Y.Y.; Tay, J.C.K.; Wang, S. CXCR1 Expression to Improve Anti-Cancer Efficacy of Intravenously Injected CAR-NK Cells in Mice with Peritoneal Xenografts. Mol. Ther. Oncolytics 2019, 16, 75-85. [CrossRef] [PubMed]

83. Li, T.; Wang, J. Therapeutic Effect of Dual CAR-T Targeting PDL1 and MUC16 Antigens on Ovarian Cancer Cells in Mice. BMC Cancer 2020, 20, 678. [CrossRef]

84. Hong, H.; Brown, C.E.; Ostberg, J.R.; Priceman, S.J.; Chang, W.C.; Weng, L.; Lin, P.; Wakabayashi, M.T.; Jensen, M.C.; Forman, S.J. L1 Cell Adhesion Molecule-Specific Chimeric Antigen Receptor-Redirected Human T Cells Exhibit Specific and Efficient Antitumor Activity against Human Ovarian Cancer in Mice. PLoS ONE 2016, 11, e0146885. [CrossRef] [PubMed]

85. Sun, M.; Shi, H.; Liu, C.; Liu, J.; Liu, X.; Sun, Y. Construction and Evaluation of a Novel Humanized HER2-specific Chimeric Receptor. Breast Cancer Res. 2014, 16, R61. [CrossRef]

86. Song, D.G.; Ye, Q.; Carpenito, C.; Poussin, M.; Wang, L.P.; Ji, C.; Figini, M.; June, C.H.; Coukos, G.; Powell, D.J., Jr. In vivo Persistence, Tumor Localization, and Antitumor Activity of CAR-engineered T Cells is Enhanced by Costimulatory Signaling through CD137 (4-1BB). Cancer Res. 2011, 71, 4617-4627. [CrossRef]

87. Perales-Puchalt, A.; Svoronos, N.; Rutkowski, M.R.; Allegrezza, M.J.; Tesone, A.J.; Payne, K.K.; Wickramasinghe, J.; Nguyen, J.M.; O'Brien, S.W.; Gumireddy, K.; et al. Follicle-Stimulating Hormone Receptor Is Expressed by Most Ovarian Cancer Subtypes and Is a Safe and Effective Immunotherapeutic Target. Clin. Cancer Res. 2017, 23, 441-453. [CrossRef] [PubMed]

88. Owens, G.L.; Sheard, V.E.; Kalaitsidou, M.; Blount, D.; Lad, Y.; Cheadle, E.J.; Edmondson, R.J.; Kooner, G.; Gilham, D.E.; Harrop, R. Preclinical Assessment of CAR T-Cell Therapy Targeting the Tumor Antigen 5T4 in Ovarian Cancer. J. Immunother. 2018, 41, 130-140. [CrossRef] [PubMed]

89. Murad, J.P.; Kozlowska, A.K.; Lee, H.J.; Ramamurthy, M.; Chang, W.C.; Yazaki, P.; Colcher, D.; Shively, J.; Cristea, M.; Forman, S.J.; et al. Effective Targeting of TAG72+ Peritoneal Ovarian Tumors via Regional Delivery of CAR-Engineered T Cells. Front. Immunol. 2018, 9, 2268. [CrossRef]

90. Hilliard, T.S. The Impact of Mesothelin in the Ovarian Cancer Tumor Microenvironment. Cancers 2018, 10, 277. [CrossRef]

91. Hassan, R.; Thomas, A.; Alewine, C.; Le, D.T.; Jaffee, E.M.; Pastan, I. Mesothelin Immunotherapy for Cancer: Ready for Prime Time? J. Clin. Oncol. 2016, 34, 4171-4179. [CrossRef]

92. Oble, D.A.; Loewe, R.; Yu, P.; Mihm, M.C., Jr. Focus on TILs: Prognostic Significance of Tumor Infiltrating Lymphocytes in Human Melanoma. Cancer Immun. 2009, 9, 3.

93. Jelovac, D.; Armstrong, D.K. Role of Farletuzumab in Epithelial Ovarian Carcinoma. Curr. Pharm. Des. 2012, 18, $3812-3815$. [CrossRef]

94. Dobrzycka, B.; Mackowiak-Matejczyk, B.; Terlikowska, K.M.; Kulesza-Bronczyk, B.; Kinalski, M.; Terlikowski, S.J. Serum Levels of IL-6, IL-8 and CRP as Prognostic Factors in Epithelial Ovarian Cancer. Eur. Cytokine Netw. 2013, 24, 106-113. [CrossRef]

95. Rodrigues, I.S.S.; Martins-Filho, A.; Micheli, D.C.; Lima, C.A.; Tavares-Murta, B.M.; Murta, E.F.C.; Nomelini, R.S. IL-6 and IL-8 as Prognostic Factors in Peritoneal Fluid of Ovarian Cancer. Immunol. Invest. 2020, 49, 510-521. [CrossRef]

96. Whilding, L.M.; Halim, L.; Draper, B.; Parente-Pereira, A.C.; Zabinski, T.; Davies, D.M.; Mahe, J. CAR T-Cells Targeting the Integrin $\alpha \mathrm{v} \beta 6$ and Co-Expressing the Chemokine Receptor CXCR2 Demonstrate Enhanced Homing and Efficacy against Several Solid Malignancies. Cancers 2019, 11, 674. [CrossRef] [PubMed]

97. Jin, L.; Tao, H.; Karachi, A.; Long, Y.; Hou, A.Y.; Na, M.; Dyson, K.A.; Grippin, A.J.; Deleyrolle, L.P.; Zhang, W.; et al. CXCR1or CXCR2-modified CAR T Cells Co-opt IL-8 for Maximal Antitumor Efficacy in Solid Tumors. Nat. Commun. 2019, $10,4016$. [CrossRef] [PubMed]

98. Taube, J.M.; Anders, R.A.; Young, G.D.; Xu, H.; Sharma, R.; McMiller, T.L.; Chen, S.; Klein, A.P.; Pardoll, D.M.; Topalian, S.L.; et al. Colocalization of Inflammatory Response with B7-h1 Expression in Human Melanocytic Lesions Supports an Adaptive Resistance Mechanism of Immune Escape. Sci. Transl. Med. 2012, 4, 127ra37. [CrossRef]

99. Fan, C.A.; Reader, J.; Roque, D.M. Review of Immune Therapies Targeting Ovarian Cancer. Curr. Treat. Options Oncol. 2018, 19, 74. [CrossRef] [PubMed]

100. Strickland, K.C.; Howitt, B.E.; Shukla, S.A.; Rodig, S.; Ritterhouse, L.L.; Liu, J.F.; Garber, J.E.; Chowdhury, D.; Wu, C.J.; D'Andrea, A.D.; et al. Association and Prognostic Significance of BRCA1/2-mutation Status with Neoantigen Load, Number of Tumor-infiltrating Lymphocytes and Expression of PD-1/PD-L1 in High Grade Serous Ovarian Cancer. Oncotarget 2016, 22, 13587-13598. [CrossRef] [PubMed]

101. Sui, X.; Ma, J.; Han, W.; Wang, X.; Fang, Y.; Li, D.; Pan, H.; Zhang, L. The Anticancer Immune Response of Anti-PD-1/PD-L1 and the Genetic Determinants of Response to Anti-PD-1/PD-L1 Antibodies in Cancer Patients. Oncotarget 2015, 6, 19393-19404. [CrossRef] [PubMed]

102. Wahba, J.; Natoli, M.; Whilding, L.M.; Parente-Pereira, A.C.; Jung, Y.; Zona, S.; Lam, E.W.-F.; Smith, J.R.; Maher, J.; Ghaem-Magham, S. Chemotherapy-induced Apoptosis, Autophagy and Cell Cycle Arrest are Key Drivers of Synergy in Chemo-immunotherapy of Epithelial Ovarian Cancer. Cancer Immunol. Immunother. 2018, 67, 1753-1765. [CrossRef] [PubMed]

103. RodrÍguez, E.; Schetters, S.T.T.; van Kooyk, Y. The Tumour Glyco-code as a Novel Immune Checkpoint for Immunotherapy. Nat. Rev. Immunol. 2018, 18, 204-211. [CrossRef] [PubMed]

104. Coelho, R.; Marcos-Silva, L.; Ricardo, S.; Ponte, F.; Costa, A.; Lopes, J.M.; David, L. Peritoneal Dissemination of Ovarian Cancer: Role of MUC16 - Mesothelin Interaction and Implications for Treatment. Expert Rev. Anticancer Ther. 2018, 18, 177-186. [CrossRef] [PubMed] 
105. Colombo, F.; Meldolesi, J. L1-CAM and N-CAM: From Adhesion Proteins to Pharmacological Targets. Trends Pharmacol. Sci. 2015, 36, 769-781. [CrossRef]

106. Hua, T.; Liu, S.; Xin, X.; Jin, Z.; Liu, Q.; Chi, S.; Wang, X.; Wang, H. Prognostic Significance of L1 Cell Adhesion Molecule in Cancer Patients: A Systematic Review and Meta-analysis. Oncotarget 2016, 7, 85196-85207. [CrossRef]

107. Oh, D.Y.; Bang, Y.J. HER2-targeted therapies-A role beyond breast cancer. Nat. Rev. Clin. Oncol. 2020, 17, 33-48. [CrossRef]

108. Wang, D.; Zhu, H.; Ye, Q.; Wang, C.; Xu, Y. Prognostic Value of KIF2A and HER2-Neu Overexpression in Patients with Epithelial Ovarian Cancer. Medicine 2016, 95, e2803. [CrossRef]

109. Ding, H.; Yang, X.; Wei, Y. Fusion Proteins of NKG2D/NKG2DL in Cancer Immunotherapy. Int. J. Mol. Sci. 2018, 19, 177. [CrossRef]

110. Zingoni, A.; Vulpis, E.; Loconte, L.; Santoni, A. NKG2D Ligand Shedding in Response to Stress: Role of ADAM10. Front. Immunol. 2020, 11, 447. [CrossRef]

111. Kang, T.H.; Mao, C.P.; He, L.; Tsai, Y.C.; Liu, K.; La, V.; Wu, T.C.; Hung, C.F. Tumor-targeted Delivery of IL-2 by NKG2D Leads to Accumulation of Antigen-specific CD8+ T Cells in the Tumor Loci and Enhanced Anti-tumor Effects. PLoS ONE 2012, 7, e35141. [CrossRef]

112. Kohrt, H.E.; Houot, R.; Marabelle, A.; Cho, H.J.; Osman, K.; Goldstein, M.; Levy, R.; Brody, J. Combination Strategies to Enhance Antitumor ADCC. Immunotherapy 2012, 4, 511-527. [CrossRef]

113. Wang, L.; Yang, R.; Zhao, L.; Zhang, X.; Xu, T.; Cui, M. Basing on uPAR-binding Fragment to Design Chimeric Antigen Receptors Triggers Antitumor Efficacy against uPAR Expressing Ovarian Cancer Cells. Biomed. Pharmacother. 2019, 117, 109173. [CrossRef]

114. van Dam, P.A.; Coelho, A.; Rolfo, C. Is There a Role for Urokinase-type Plasminogen Activator Inhibitors as Maintenance Therapy in Patients with Ovarian Cancer? Eur. J. Surg. Oncol. 2017, 43, 252-257. [CrossRef]

115. Yadav, A.S.; Pandey, P.R.; Butti, R.; Radharani, N.N.V.; Roy, S.; Bhalara, S.R.; Gorain, M.; Kundu, G.C.; Kumar, D. The Biology and Therapeutic Implications of Tumor Dormancy and Reactivation. Front Oncol. 2018, 8, 72. [CrossRef]

116. Stern, P.L.; Harrop, R. 5T4 Oncofoetal Antigen: An Attractive Target for Immune Intervention in Cancer. Cancer Immunol. Immunother. 2017, 66, 415-426. [CrossRef]

117. Wan, Y.L.; Sapra, P.; Bolton, J.; Chua, J.X.; Durrant, L.G.; Stern, P.L. Combination Treatment with an Antibody-Drug Conjugate (A1mcMMAF) Targeting the Oncofetal Glycoprotein 5T4 and Carboplatin Improves Survival in a Xenograft Model of Ovarian Cancer. Target. Oncol. 2019, 14, 465-477. [CrossRef] [PubMed]

118. Yan, W.; Hu, H.; Tang, B. Advances of Chimeric Antigen Receptor T Cell Therapy in Ovarian Cancer. OncoTargets Ther. 2019, 12, 8015-8022. [CrossRef] [PubMed]

119. Jindal, V.; Arora, E.; Gupta, S.; Lal, A.; Masab, M.; Potdar, R. Prospects of Chimeric Antigen Receptor T Cell Therapy in Ovarian Cancer. Med. Oncol. 2018, 35, 70. [CrossRef]

120. Marofi, F.; Motavalli, R.; Safonov, V.A.; Thangavelu, L.; Yumashev, A.V.; Alexander, M.; Shomali, N.; Chartrand, M.S.; Pathak, Y.; Jarahian, M.; et al. CAR T Cells in Solid Tumors: Challenges and Opportunities. Stem Cell Res. Ther. 2021, 12, 81. [CrossRef] [PubMed]

121. Wright, S.E.; Rewers-Felkins, K.A.; Quinlin, I.S.; Phillips, C.A.; Townsend, M.; Philip, R.; Dobrzanski, M.J.; Lockwood-Cooke, P.R.; Robinson, W. Cytotoxic T-lymphocyte Immunotherapy for Ovarian Cancer: A Pilot Study. J. Immunother. 2012, 35, 196-204. [CrossRef]

122. Haas, A.R.; Tanyi, J.L.; O’Hara, M.H.; Gladney, W.L.; Lacey, S.F.; Torigian, D.A.; Soulen, M.C.; Tian, L.; McGarvey, M.; Nelson, A.M.; et al. Phase I Study of Lentiviral-Transduced Chimeric Antigen Receptor-Modified T Cells Recognizing Mesothelin in Advanced Solid Cancers. Mol. Ther. 2019, 27, 1919-1929. [CrossRef]

123. Morgan, M.A.; Schambach, A. Engineering CAR-T Cells for Improved Function Against Solid Tumors. Front. Immunol. 2018, 9, 2493. [CrossRef] [PubMed]

124. Benard, E.; Casey, N.P.; Inderberg, E.M.; Wälchli, S. SJI 2020 Special Issue: A Catalogue of Ovarian Cancer Targets for CAR Therapy. Scand. J. Immunol. 2020, 92, e12917. [CrossRef] [PubMed]

125. Ueda, T.; Kumagai, A.; Iriguchi, S.; Yasui, Y.; Miyasaka, T.; Nakagoshi, K.; Nakane, K.; Saito, K.; Takahashi, M.; Sasaki, A.; et al. Non-clinical Efficacy, Safety and Stable Clinical Cell Processing of Induced Pluripotent Stem Cell-derived Anti-glypican-3 Chimeric Antigen Receptor-expressing Natural Killer/Innate Lymphoid Cells. Cancer Sci. 2020, 111, 1478-1490. [CrossRef]

126. Wang, L.; Xu, T.; Cui, M. Are Ovarian Cancer Stem Cells the Target for Innovative Immunotherapy? OncoTargets Ther. 2018, 11, 2615-2626. [CrossRef]

127. Parte, S.C.; Batra, S.K.; Kakar, S.S. Characterization of Stem Cell and Cancer Stem Cell Populations in Ovary and Ovarian Tumors. J. Ovarian Res. 2018, 11, 69. [CrossRef]

128. Zhao, L.; Li, J.; Liu, M.; Zhou, H.; Zou, H.; Wei, Y.; Sun, K.; Li, G.; Li, S.; Pang, L. The Clinicopathological Parameters Significance of CD133 and Nestin in Epithelial Ovarian Cancer: A Meta-analysis. Future Oncol. 2017, 13, 2555-2570. [CrossRef] [PubMed] 